\title{
A LEI DE ACESSO À INFORMAÇÃO COMO FORMA DE CONCRETIZAÇÃO DO DIREITO Ã VERDADE NA JUSTIÇA TRANSICIONAL BRASILEIRA
}

\author{
THE ACCESS TO INFORMATION LAW AS THE SUBSTANTIATION OF RIGHT \\ TO THE TRUTH IN BRAZILIAN TRANSITIONAL JUSTICE
}

Tiago Kalkmann

\begin{abstract}
Mestre em Direito pela Universidade Federal do Rio Grande do Sul (UFRGS). Especialista em Direito Penal e Processual Penal pelo Instituto Brasiliense de Direito Público. Graduado em Direito pela Universidade de Brasília.

E-mail: tykalk@hotmail.com
\end{abstract}

Recebido em: 17/11/2017

Aprovado em: 16/02/2019

RESUMO: o trabalho busca analisar a relação entre o movimento de justiça transicional e os mecanismos de acesso à informação. A Justiça de Transição, enquanto movimento político e jurídico, encontrou no Brasil desafios à sua completa implantação. Dentre as quatro frentes principais de ação dos mecanismos transicionais, apenas as reformas institucionais (com ressalvas) e os mecanismos compensatórios foram implantados a tempo, vindo o direito à verdade a ser garantido apenas muito tempo após a queda do regime. $\mathrm{O}$ direito à verdade não busca substituir a narrativa oficial, mas inserir novas referências na história através de seu confronto com a memória. Os documentos do regime militar são essenciais, mas seu acesso foi bloqueado pelo governo brasileiro durante muitos anos. Apenas através de impulsos externos, foi possível a promulgação da Lei $\mathrm{n}^{\mathrm{o}} 12.527 / 2011$, que modernizou o direito de acesso à informação. As mudanças trazidas pela nova lei, com as alterações das possibilidades e prazos de sigilo, aliadas à ação da Comissão de Verdade, possibilitaram momento de abertura de arquivos da repressão. Este movimento ajudou na modernização de direitos fundamentais e do direito administrativo, além de contribuir para uma aproximação do princípio da publicidade de sua feição substancial.

Palavras-chave: Justiça de Transição. Direito à Verdade. Arquivos da repressão. Direito de Acesso à Informação. Publicidade.

ABSTRACT: this work aims to expose the relation between transitional justice and access to information mechanisms. Transitional Justice, as a political and legal movement, found in Brazil challenges to its complete application. Out of the four main transitional fronts, only the institutional renovation (with reservations) e the compensatory instruments were timely implanted. The right to the truth came much later, more than twenty years after the end of the military regime. The right to the truth is not a way to supplant the official history, but a manner to insert new references in history athwart its confrontation with living memory. Thereunto are the files from the military regime essential, yet Brazilian government restricted its access for more than twenty years. Merely due to external impetus was made possible the promulgation of the 
Law $\mathrm{n}^{\mathrm{o}} 12.527 / 2001$, updating the right of access to information. The updates brought upon by the aforementioned legislation, ranging from limiting secrecy hypothesis to redefining its terms, allied to the actions of the National Truth Committee, made possible the improvement of fundamental rights and administrative law. Besides, it contributed to an approximation of the publicity principle to its material regard.

Keywords: Transitional Justice. Right to the Truth. Repression Files. Right of Access to Information. Publicity.

SUMÁRIO: Introdução. 1. A Justiça de Transição e o Direito à Verdade. 1.1 O Significado de Justiça Transicional e o Caso Brasileiro. 1.2. O Direito à Verdade e o Princípio da Publicidade. 1.3. Acesso a Documentos do Regime Militar Brasileiro após a Constituição Federal de 1988. 1.4. A Construção da Memória Histórica e a Comissão Nacional da Verdade. 2. A Abertura da Lei de Acesso à Informação e os Desafios Remanescentes de Acesso a Arquivos. 2.1. Os Componentes de um Direito Fundamental à Informação. 2.2. O Contexto da Inauguração da Lei $n^{\circ}$ 12.527/2011. 2.3. Mecanismos de Facilitação de Acesso e Redução dos Prazos de Sigilo. 2.4. Impulso à Abertura de Arquivos Públicos. 2.5. Desafios de Aplicação da Legislação. Conclusão. Referências Bibliográficas.

\section{INTRODUÇÃO}

O presente artigo tem por objetivo verificar se os institutos contidos na Lei de Acesso à Informação (Lei $\mathrm{n}^{\circ}$ 12.527/2011) ajudaram ou não na concretização do direito à verdade e na alteração de paradigma da justiça de transição brasileira. Para essa finalidade, serão analisadas as mudanças trazidas pela legislação ao direito de acesso à informação, bem como as aberturas de arquivos por elas acarretadas.

Em último plano, a hipótese central é de que as intercorrências da justiça transicional com o direito administrativo facilitaram o acesso a documentos do período ditatorial e aproximaram o princípio da publicidade de um paradigma material, contribuindo para a superação de uma visão meramente formalista da publicação dos atos administrativos e auxiliando na concretização do direito à verdade.

Primeiramente, será abordado o conceito de justiça de transição dentro do direito internacional e da proteção dos direitos humanos, em especial no contexto pós-autoritarismo na América latina. Ainda, serão ressaltadas as peculiaridades do processo transicional brasileiro.

Em seguida, o foco passará ao direito a verdade enquanto componente da justiça de transição. Neste plano, demonstrará como tal direito se relaciona com o próprio princípio da publicidade inerente à administração pública e o direito de acesso à informação.

Dentro da noção de direito à verdade, será explicitado como o acesso aos documentos do regime militar brasileiro pode ser considerado, em regra, como sigiloso pela legislação pela maior parte do período após a promulgação da Constituição Federal de 1988.

Tal situação, todavia, foi alterada com as novas possibilidades de construção de memória histórica abertas com a Comissão Nacional da Verdade e com a nova Lei de Acesso à Informação. TORELLY (2012) já diz, inclusive, que se trata de um terceiro momento da anistia brasileira, ou seja, um novo paradigma transicional ${ }^{1}$.

\footnotetext{
${ }^{1}$ As considerações do autor, entretanto, podem ser refutadas, pois o autor previu inicialmente uma magnitude às alterações que não foi efetivamente alcançada. Segundo TORELLY (2012), as alterações poderiam ser consideradas uma indicação de superação da anistia-impunidade assegurada pelo STF. Contudo, tal movimento não demonstra sinais no momento, em que a própria reivindicação transicional esfria em face de novos contextos políticos que demandam a atuação da Suprema Corte.
}

Revista de Direito Brasileira | Florianópolis, SC | v. 23 | n. 9 | p. 83-111 |Mai./Ago. 2019 
Partindo desse pressuposto, será abordado como o direito de acesso à informação vem sendo considerado um direito fundamental por grande parte das Constituições. explicitando os componentes jurídicos desse direito segundo a doutrina e as regras internacionais.

Tal direito foi implantado efetivamente na ordem interna brasileira em momento recente, motivado principalmente pela decisão do caso Gomes Lund pela Corte Interamericana de Direitos Humanos. Na ocasião, foi determinada a adoção de medidas transicionais pelo governo brasileiro, especialmente o acesso à informação oficial do período ditatorial ${ }^{2}$. Apenas após estes influxos internacionais e as inúmeras críticas feitas à regulamentação do acesso à informação é que foi promulgada a atual Lei de Acesso à Informação (Lei no 12.527/2011) ${ }^{3}$

Em seguida, passar-se-á a tratar desse direito no âmbito interno, especialmente do trato legislativo ao acesso à informação. Serão abordados alguns dos principais institutos da lei e críticas que lhe são feitas. Dar-se-á especial atenção aos mecanismos relacionados à defesa de direitos humanos, de relação direta com a matéria debatida no artigo, e à redução dos prazos de sigilo e hipóteses fundamentadoras.

A fim de verificar a influência material desse processo legislativo e dogmático, o artigo analisará empiricamente o incremento no acesso a documentação e a abertura de arquivos da ditadura outrora sigilosos, representado pelo franqueamento de acesso exofficio por diversos órgãos públicos.

Entretanto, mostrar-se-á como ainda restam desafios e locais onde a nova legislação não é aplicada. Existem muitos arquivos ainda ocultos e muitas possibilidades e demandas a serem cumpridas por comissões estaduais e por organizações de direitos humanos, mostrando novas possibilidades de expansão das fronteiras do processo transicional antes que seja completamente ofuscado.

Dessa forma, a hipótese a ser verificada é de que a Lei de Acesso à Informação e a Comissão Nacional da Verdade influenciaram um movimento de abertura de arquivos da repressão e podem ser vistas como avanços, ainda que pequenos, no sentido de possibilitar consciência democrática e compreensão da história e da memória.

Além disso, concluir-se-á que os mecanismos legais e o direito administrativo, como no exemplo desse artigo, podem e devem ser utilizados como mecanismos também de busca dos direitos humanos e de esclarecimento da população. De outro lado, a justiça de transição, ainda quando externamente impulsionada, pode alterar e ressignificar conceitos e institutos do direito interno, contribuindo, no caso do acesso à informação, à sua efetiva aplicação.

\section{A JUSTIÇA DE TRANSIÇÃO E O DIREITO À VERDADE}

A justiça de transição pode ser conceituada como o conjunto de mecanismos utilizados como maneira de readequar a sociedade e o poder público após o fím de regimes totalitários ou autoritários $^{4}$. Dessa maneira, a transição de que se trata ocorre entre autoritarismo e democracia.

\footnotetext{
${ }^{2}$ A decisão da corte internacional exigiu ainda a implantação de diversas outras medidas transicionais, a maioria nunca cumprida pelo Brasil. A mais notória é a exigência de punição dos perpetradores de graves violações de direitos humanos, medida que encontra óbice na jurisprudência do STF.

${ }^{3}$ Em razão desse e de outros elementos é que se entende que o processo transicional brasileiro é essencialmente extraoficial, ou seja, suas maiores alterações foram resultados de esforços de arenas políticas informais ou órgãos internacionais.

${ }^{4} \mathrm{O}$ termo justiça de transição foi cunhado pela professora Ruti TEITEL (2003) para se referir aos processos latino americanos de readaptação da sociedade civil e da esfera pública à abertura democrática após períodos de ditadura. Todavia, o termo passou a ser adotado para se referir a processos semelhantes ao redor do mundo.
} 
É primordialmente um movimento político, mas que se revela em diversos instrumentos jurídicos, entre eles o direito à verdade e à construção da memória histórica, de fundamental importância para o objeto deste artigo.

Os processos transicionais estão presentes em diversos momentos históricos e em diferentes contextos geográficos e sociais, com presença marcante no Leste Europeu e na América Latina ${ }^{5}$. Em razão das inúmeras diferenças que podem ser constatadas entre os diversos processos, os próximos tópicos buscarão tratar de elementos que identifiquem a justiça de transição e suas características no caso brasileiro.

\subsection{O Significado de Justiça Transicional e o Caso Brasileiro}

Segundo a professora Ruti TEITEL (2003), a função do direito, em um paradigma de transição, é construir a mudança política. O direito é constitutivo da política de transição, enquanto é também por ela constituído. A professora cita três fases essenciais ${ }^{6}$ para a compreensão do fenômeno, iniciando pelo Tribunal de Nuremberg, passando pelo processo latino-americano e culminando no paradigma globalizado, como um consenso em torno da necessidade de se lidar com o passado ${ }^{7}$.

Justiça de transição, portanto, é um movimento político e jurídico. CUYA (2011) ressalta que antigamente se falava em justiça restaurativa ${ }^{8}$, mas hoje se fala em justiça transicional. Segundo o autor, esta pode ser definida como o conjunto de medidas direcionadas a superar os graves danos causados à sociedade por regimes totalitários ou ditatoriais (anomalia constitucional) que cometem violações aos direitos humanos contra pessoas ou grupos de uma determinada nação. As medidas não são frutos de um tratado ou acordo internacional, até porque seus efeitos são primordialmente internos; todavia, nutre-se dos instrumentos de proteção aos direitos humanos internacionalmente consagrados ${ }^{9}$ (CUYA, 2011).

Dessa forma, adotando o paradigma de AGAMBEN (2004), pode-se situar a justiça de transição na saída de um momento de exceção. O momento de exceção, segundo o autor, não é estado propriamente dito: não existe um "direito" de exceção ${ }^{10}$. Com base nessas colocações, podemos afirmar que a justiça de transição busca retirar o paradigma de exceção para a implantação da democracia ${ }^{11}$.

\footnotetext{
${ }^{5}$ Mais recentemente, o fenômeno político se torna comum em países africanos e em nações do Oriente Médio, mormente após o movimento denominado de "Primavera Árabe".

${ }^{6}$ A primeira onda de transição era internacional e punitivista. A segunda fase identificada por TEITEL (2003) possui uma mudança de ênfase. Sai da punição para processos comunitários de superação do passado e reconciliação nacional. $\mathrm{O}$ direito à verdade assumiria um papel ainda maior. A terceira fase manteria esta nova ênfase, dessa vez como um paradigma globalizado.

7 Poder-se-ia contrapor ao trabalho da professora os fenômenos de transição observados no Leste Europeu, principalmente após a queda da ex-Iugoslávia. Todavia, a análise proposta pela professora não limita os países onde se observa a justiça de transição, servindo apenas como corte metodológico para análise das características comuns.

${ }^{8}$ A justiça restaurativa é um modelo alternativo ao sistema penal retributivista que busca solucionar o conflito de forma colaborativa com maior participação do infrator e da vítima. No contexto aqui utilizado, denota-se que a colaboração entre violador de direitos humanos e violado para a composição do conflito (justiça restaurativa) cede espaço para uma série de mecanismos, de alcance mais amplo, denominados de justiça de transição.

${ }^{9}$ CUYA (2011) vê os instrumentos de transição como necessários para a própria implantação de uma ordem democrática sólida. Segundo o autor, países que se recusam a punir os violadores de direitos humanos não conseguirão implantar uma democracia efetiva, pois seu surgimento estará assentado em impunidade e esquecimento apenas.

${ }^{10}$ AGAMBEN (2004) pontua que, na realidade, o estado de exceção não é interior nem exterior ao direito, mas uma genuína zona de indiferença a tudo que é jurídico.

${ }^{11} \mathrm{Na}$ realidade, por ser a exceção um estado de indiferença ao direito, qualquer "juridicização" do espaço requereria a implantação de medidas de transição, não apenas a implantação da democracia. Contudo, para os fins da doutrina relacionada ao direito transicional aqui referenciada, trata-se de um movimento com sentido democrático.
}

Revista de Direito Brasileira | Florianópolis, SC | v. 23 | n. 9 | p. 83-111 |Mai./Ago. 2019 
A Organização das Nações Unidas traça quatro medidas básicas para a concretização de um processo transicional: 1 - a busca da verdade sobre os crimes e construção da memória; 2 punição e justiça contra os violadores dos direitos humanos; 3 - medidas de reparação materiais ou morais às vítimas; 4 - reformas institucionais de amplo alcance que impeçam a repetição das violações $^{12}$.

Estes mecanismos são resultado de grande esforço de consolidação pela doutrina e por organismos internacionais, possuindo como características centrais a circularidade, complementaridade e contextualidade ${ }^{13}$ (ABRÃO, TORELLY, 2012).

Para compreendermos melhor como ocorreu e ocorre o processo transicional no Brasil, devemos situar a fonte do regime de exceção bem como a fonte do processo transicional. TORELLY (2012), com base nos estudos de Jon Elster, diferencia o autoritarismo e a transição endógenos e exógenos, cada um com suas peculiaridades. No caso brasileiro, tanto o autoritarismo quanto a transição possuem motivação endógenas, segundo o autor. Isso quer dizer que não apenas nossa ditadura foi implantada sem ação de agentes externos, como também nosso processo transicional foi internamente iniciado. Aliás, essa é a ideia por trás do conhecido chavão da "abertura política lenta, gradual e segura"14 e da alegada "vitória de todos"15.

Entretanto, tal concepção de transição endógena serve para elucidar o início do processo, mas é insuficiente para compreender seu desenvolvimento. Na realidade, após a abertura política e a promulgação da nova Constituição Federal, as medidas de transição perderam seu impulso oficial endógeno. SANTOS (2010) destaca como a atuação do próprio estado na justiça de transição brasileira foi contraditória, sendo que os próprios atores internacionais e internos de direitos humanos é que foram responsáveis por uma constante reivindicação e ressignificação da justiça de transição ${ }^{16}$.

O processo transicional brasileiro foi iniciado com a Lei de Anistia (Lei no 6.683/1979), que trouxe perdão a todos os perseguidos políticos e também aos militares que cometeram violações aos direitos humanos (o já citado paradoxo da "vitória de todos"). A anistia, que era inicialmente vista como liberdade, foi tratada como impunidade e esquecimento (ABRAÃO, TORELLY, 2012).

Segundo os mesmos autores, teria sido iniciada uma nova fase no processo transicional com a promulgação da Constituição Federal de 1988 e do art. $8^{\circ}$ do ADCT, prevendo a identificação das vítimas de perseguição e o pagamento de indenizações ${ }^{17}$. Tal fase teria alterado o eixo da justiça de transição para a liberdade e reparação (ABRAÃO, TORELLY, 2012). Contudo, é notório como o desenvolvimento de nossos mecanismos de transição se deu com considerável atraso em comparação com outros países da América Latina (RODRIGUES, 2014).

\footnotetext{
12 A este respeito, veja o relatório do Secretário-Geral submetido ao Conselho de Segurança nº 616/2004, por exemplo.

13 Segundo a circularidade, cada um dos mecanismos leva à aplicação do outro, em razão de sua complementariedade. A contextualidade, por sua vez, afirma que a forma de aplicação será adaptada a cada contexto político transicional.

${ }^{14}$ Este "bordão" histórico faz referência ao processo de abertura iniciado no governo do presidente-ditador Ernesto Geisel, em 1975. A abertura tinha o objetivo de assegurar a base autoritária do Estado e, de fato, foi realizada de forma tão lenta que sua redemocratização veio efetivamente apenas dez anos depois.

15 A "vitória de todos" é utilizada para fazer referência à Lei de Anistia, que perdoou não apenas os perseguidos políticos do regime, mas também os perpetradores das graves violações de direitos humanos.

${ }^{16}$ Em especial, deve ser destacado o papel da Comissão e da Corte Interamericanas de Direitos Humanos. Tanto as medidas de reparação das vítimas bem como a Comissão da Verdade foram implantadas em momentos de grande pressão por medidas concretas por parte do sistema de direitos humanos.

17 Tal previsão se coaduna com o pilar da reparação, já descrito entre as peças fundamentais da justiça de transição. Contudo, a concretização de tal previsão só ocorreu em 1995 com a criação da Comissão Especial sobre Mortos e Desaparecidos Políticos. Tal comissão foi criada em razão de grande pressão externa exercida pelo início das investigações do caso Gomes Lund pela Comissão Interamericana de Direitos Humanos.
}

Revista de Direito Brasileira | Florianópolis, SC | v. 23 | n. 9 | p.83-111 |Mai./Ago. 2019 
Aliás, como já citado, ao contrário do que aconteceu em diversos outros países submetidos a regimes de transição, o Brasil não assistiu à responsabilização judicial dos perpetradores das violações de direitos humanos, em razão da aplicação da Lei de Anistia e sua chancela pelo STF. Tal situação implica constantes demandas no campo do direito, que seguem desatendidas $^{18}$ (RODRIGUES, 2014).

Irene NOHARA (2009) acentua que a "vitória de todos" imposta pelo regime militar não destoa de um histórico político brasileiro, marcado por práticas abusivas de poder. Tal tradição poderia explicar a pouca "revolta" que gera essa situação em nossa democracia pós-88:

Lamentavelmente, não é inédita na tradição histórica brasileira a justificativa com base em uma transição pseudoconsensual, feita "de cima para baixo", ou seja, a partir de um acordo entre as elites interessadas e os agentes detentores de poder. Assim, em vez de se vivenciar uma ruptura de paradigma, na instauração da ordem democrática, efetivada por novos sujeitos políticos, o que faria com que o Estado fosse forçado a assumir todas as consequências pelos abusos perpetrados contra pessoas no período anterior, experienciou-se no Brasil tão somente um "assujeitamento" daqueles que foram banidos da arena política. (NOHARA, 2009, p. 137).

A autora prossegue apontando os reflexos da impunidade e do assujeitamento em outros pilares do sistema de transição, em especial a reparação ${ }^{19}$. As vítimas de perseguição foram reparadas, mas a instrumentalização de tais indenizações foi feita de maneira errônea pelo estado, pois este teve de arcar integralmente com todos os custos sem responsabilizar os reais agentes dos ilícitos em ação regressiva e descobrir os reais perpetradores dos ilícitos ${ }^{20}$.

Por fim, o pilar do direito à verdade foi o último a ser desenvolvido com as atividades recentes da Comissão Nacional da Verdade e a promulgação da Lei de Acesso à Informação (Lei $\left.\mathrm{n}^{\mathrm{o}} 12.527 / 2011\right)$.

Quanto ao ponto, não se pode negar a importância representada pelas comissões de reparação. O Brasil teve duas comissões de reparação: a Comissão Especial sobre Mortos e Desaparecidos Políticos, que funcionou entre 1995 e 2007, e a Comissão de Anistia, atuante entre 2001 e o presente. Embora inicialmente visassem a reparação, foram instrumentos para que o Estado reconhecesse oficialmente a existência de vítimas e suas narrativa ${ }^{21}$, fazendo com que produzissem verdade, ainda que de forma indireta e mediata (ABRAÃO, TORELLY, 2012).

$\mathrm{O}$ resultado é que as comissões de reparação possibilitaram o exercício do direito à verdade mesmo antes de sua positivação em nosso ordenamento. $\mathrm{O}$ acervo das comissões (em especial da Comissão de Anistia) constitui registro valioso de transgressões históricas, contendo testemunhos e documentos da violência estatal que são úteis ao conhecimento de um período

\footnotetext{
${ }^{18}$ Para RODRIGUES (2014), a justiça de transição “à brasileira” marcada pelo atraso (e pela impunidade) apresenta uma vantagem estratégica no campo dos direitos humanos, pois conta com a observação de outras experiências sulamericanas, em especial as da Argentina, Chile e Uruguai.

${ }^{19}$ Tais interferências de um instrumentos em outro reiteram as características de circularidade e complementariedade já expostas anteriormente. Desse ponto de vista, é reforçada a compreensão de que nenhum dos instrumentos poderá ser aplicado em seu inteiro potencial enquanto persistir a impunidade em nosso sistema jurídico.

${ }^{20}$ A responsabilidade do estado, apesar de objetiva, não pode implicar em prejuízo excessivo aos cofres públicos, uma vez que os encargos sociais são repartidos por toda a população. Nesse sentido, apurar em ação regressiva o grau de dano e culpa dos agentes responsáveis pelo manejo abusivo da máquina de repressão constitui dever-poder da Administração Pública. Tal apuração, todavia, não foi realizada, gerando uma excessiva responsabilização, violando a própria transparência da atuação e das contas públicas.

${ }^{21} \mathrm{Na}$ realidade, os trabalhos das comissões de reparações constituíram o primeiro espaço onde de fato houve reconhecimento de culpa pelo estado brasileiro de forma circunstanciada, diferente de uma confissão genérica. Aqui, houve a construção de narrativas específicas, indicando nomes de torturados e as circunstâncias em que cometidos os atos ilícitos.
}

Revista de Direito Brasileira | Florianópolis, SC | v. 23 | n. 9 | p. 83-111 |Mai./Ago. 2019 
mantido no escuro. Aliás, o desfazimento das narrativas oficiais do estado pela narrativa das vítimas foi a linha que passou a ser seguida também pelo trabalho da Comissão Nacional da Verdade $^{22}$.

Tal trabalho, por óbvio, não esgotou o esforço de memória histórica, tampouco concretizou de fato o direito à verdade em sua concepção humanística. Entretanto, mantida a impunidade jurídica, foi o primeiro passo à eliminação de nossa impunidade histórica.

\subsection{O Direito à Verdade e o Princípio da Publicidade}

A verdade não pode ser considerada um fato filosófico uniformemente verificável; pelo contrário, sua extração ocorre sempre através de disputa (PONTA, ZAMBOTTO, 2016).

FOUCAULT (2002) diferencia a verdade da ciência e a verdade social. Segundo ele, a verdade social só pode ser alcançada mediante o respeito às regras do jogo da comunidade ${ }^{23}$. Nietzsche, por sua vez, entende que é impossível definir a verdade, sendo essa apenas um ponto de vista ${ }^{24}$. SIMON (2011) diferencia ainda a verdade do ponto de vista jurídico, decorrente da lógica argumentativa, e a verdade política, que assume contornos de medida de pacificação social $^{25}$.

Para Hannah ARENDT (2003), a verdade depende essencialmente do autoengano, ou seja, deve ser aceita por aquele que a proclama sem hesitação. De fato, tal colocação seria perfeitamente aplicável ao contexto de nossa redemocratização: o engano do acordo nacional e do esquecimento, conferindo aura de verdade à informação oficial. Entretanto, a autora destaca que o autoengano não transforma realmente a mentira em verdade ${ }^{26}$. Conforme reflete Hannah Arendt, existe sim uma possibilidade de a verdade, por vontade do Estado, ser "recontada" pela história. Todavia, alguns dados se tornam tão públicos que não há como um Estado flexibilizar a verdade, por mais espinhosa que seja. A ditadura ocorrida no Brasil é um exemplo disso, e a Alemanha Nazista é outro. A autora arremata que "a verdade é odiada por tiranos, que temem com razão a competição de uma forma coercitiva que não podem monopolizar" (ARENDT, 2003, p. 298).

Infelizmente, a instauração de uma verdade através do autoengano e da imposição é comum não só na experiência brasileira, mas na América Latina amplamente considerada. Com medo do que a verdade pode representar em momentos de crise, os acordos entre elites detentoras de poder servem para a aplicação heterônoma do autoengano, fazendo com que a ruptura de paradigma seja evitada por meio de uma história "recontada" (NOHARA, 2009). Uma forma de evitar tal fenômeno, conforme já destacado por ARENDT (2003), é tornar públicas as demais narrativas de forma a evitar a manipulação pela estrutura de poder ${ }^{27}$.

\footnotetext{
${ }^{22} \mathrm{O}$ trabalho iniciado neste período e aprimorado com a criação da Comissão Nacional da Verdade fez com que ABRAÃO e TORELLY (2012) declarassem o início de um novo foco em nosso processo transicional, voltado para o eixo "liberdade e justiça".

${ }^{23}$ Para FOUCAULT (2002), a verdade científica é dotada de consenso justamente por ser fruto de uma comunidade científica. A verdade social, entretanto, não é dotada de verificação nos moldes científicos, e sua aceitação depende do procedimento através do qual foi extraída. A verdade penal, por exemplo, é essencialmente dependente da observância das regras processuais.

${ }^{24}$ Tal concepção de forma alguma contraria a premissa de um direito à verdade. Pelo contrário, a concepção de verdade como um simples ponto de vista explica a necessidade de inclusão de diversas narrativas no mesmo período histórico, uma vez que nenhuma delas pode ser considerada superior simplesmente por ser oriunda de fonte oficial.

25 Neste ponto, SIMON (2011) contrapõe o entendimento de FOUCAULT (2002). Segundo o primeiro autor, a lógica processual penal não é adequada para desvendar a verdade sobre graves violações aos direitos humanos, pois esta está sujeita a uma verdade de conformação política.

${ }^{26} \mathrm{O}$ contexto de autoengano seria utilizado pela autora como uma representação da mentira para fins políticos e de perpetuação do poder.

${ }^{27} \mathrm{Na}$ realidade, a manipulação pelo poder organizado é inevitável, em razão do peso que acarreta a verdade. A abertura do espaço de construção da história para outras perspectivas, contudo, frustra, ainda que incompletamente,

Revista de Direito Brasileira | Florianópolis, SC | v. 23 | n. 9 | p.83-111 |Mai./Ago. 2019
} 
Conforme já ressaltado por AGAMBEN (2003), o espaço de exceção é indiferente e alheio ao direito, embora ainda finja que aplique o jurídico:

$\mathrm{O}$ aspecto normativo do direito pode ser, assim, impunemente eliminado e contestado por uma violência governamental que, ao ignorar no âmbito externo o direito internacional e produzir no âmbito interno um estado de exceção permanente, pretende, no entanto, ainda aplicar o direito (AGAMBEN, 2003, p. 131).

Essa suposta aplicação do direito se assemelha à proposição do autoengano em Hannah ARENDT (2003). Sob essa suposta preservação do direito, pretende-se também consagrar uma verdade. Contudo, embora o estado de exceção permita o engano jurídico e da verdade, a verdade por ele proposta é vazia, ainda que documentada, pois não se pode consagrar uma verdade onde o espaço é de indiferença a tudo quanto possa ser utilizado como imposição de ordem. $\mathrm{O}$ direito à verdade seria a possibilidade de inserção de narrativas na história contada como pretensamente verdadeira, embora seja, na verdade, vazia, desprovida de significado e farta de documentação escrita $^{28}$ (AGAMBEN, 2003).

O "direito de saber" é exercido pelo simples acesso a essa narrativa oficial. CUYA (2011) destaca, citando o teórico Louis Joinet, que tal direito é essencialmente exercido por meio da farta documentação produzida por regimes ditatoriais ${ }^{29}$. É primordial, para esse fim, que os arquivos das violações sejam preservados, com inventários, controle de acesso (não discricionário) e medidas de prevenção de sua destruição ${ }^{30}$.

Apesar de essencial ao exercício do direito à verdade, o "direito de saber" com ele não se confunde. $\mathrm{O}$ direito à verdade possui maior magnitude, assumindo contornos de direito à construção de memória histórica.

Em 1985, a Corte Interamericana de Direitos Humanos afirmou expressamente a existência de um direito fundamental à verdade. Em 2001, tal garantia foi reafirmada no julgamento do caso Barrios Altos Vs. Perú.

Também a Comissão de Direitos Humanos da Organização da Nações Unidas prevê expressamente o direito à verdade (Resolução 2005/66), nos seguintes termos:

(...) cada povo tem o direito inalienável de conhecer a verdade sobre os acontecimentos do passado em relação a crimes hediondos perpetrados, bem

tentativas de engano apresentadas por esferas dominantes, possibilitando constante diálogo e intervenção de grupos outrora banidos.

${ }^{28}$ Prosseguindo no modelo proposto por AGAMBEN (2003), o estado de exceção é um espaço indiferente e isento à verdade, embora pretenda construi-la e conta-la. Assim como o direito pretensamente aplicado, que não reflete estruturas realmente jurídicas, a verdade de exceção é fruto do autoengano e de um suporte documental que pretende lhe conferir ares de autenticidade. Da mesma forma como o "direito" de exceção é composto por leis, a verdade de exceção é composta por inúmeros documentos. O vazio de tais espaços, contudo, é percebido a partir do momento em que se abrem múltiplas narrativas, fragilizando a história oficialmente contada. Por isso se afirma que o direito à verdade, para fins deste trabalho, é a possibilidade de inserir narrativas no espaço vazio e desprovido de autenticidade. Não há pretensão de que tais narrativas inseridas no vazio venham a ser consideradas como única fonte legítima de história, mas como uma dentre inúmeras fontes contrapostas que assegurem a representatividade de determinado grupo.

${ }^{29}$ Uma característica comum aos regimes militares, apontada pelo autor, é a produção de um grande acervo documental (CUYA, 2011). Além da formalidade ser inerente às estruturas militares tradicionais, é notório o uso de documentos como forma de contar a história de forma que pareça oficial. Deve-se ter cuidado, portanto, com a grande quantidade de mentiras que se encontram nos documentos oficiais (GREEN, 2011).

${ }^{30}$ Tais medidas são de suma importância, pois, como demonstra a experiência histórica, é comum que os grupos depostos do poder busquem destruir ou inutilizar os documentos produzidos durante seu período no poder. O Brasil não é exceção a esta experiência, como demonstra a grande quantidade de documentos desaparecidos ou inacessíveis, ou os inúmeros relatos de destruição de documentos por Comandos das Forças Armadas.

Revista de Direito Brasileira | Florianópolis, SC | v. 23 | n. 9 | p. 83-111 |Mai./Ago. 2019 
como sobre as circunstâncias e motivos que, mediante violações massivas ou sistemáticas, à sua realização. O exercício pleno e efetivo do direito à verdade proporciona uma defesa fundamental contra a repetição de tal violência. ${ }^{31}$

O direito à verdade, na concepção até aqui exposta, se relaciona fundamentalmente com a publicidade da administração pública, mormente quando considerado sob a ótica do "direito de saber". Demanda-se que seja garantido, em nome da publicidade, um arcabouço verdadeiro e suficiente de informações que possibilitem a real participação política.

Ademais, a informação e o acesso a ela hoje se afiguram como condição de possibilidade da própria democracia, da igualdade e da liberdade. No texto constitucional vigente, podem-se destacar diversas previsões normativas muito claras nesse sentido, dentre as quais se destaca a essencialidade da exigência de publicidade dos atos da administração pública como requisito de vigência do ato ${ }^{32}$ (CUYA, 2011).

As diversas previsões constitucionais constituem, no plano formal, requisitos instrumentais da participação política e do controle social da administração pública. A verdade e a falseabilidade das informações públicas, enquanto componentes do princípio da publicidade, demandam que as informações divulgadas pelos órgãos oficiais sejam motivadas pela veracidade, sem distorções ou finalidades ocultas. Além disso, é necessário que seja possibilitada a contestação e correção das informações divulgadas pela administração ${ }^{33}$.

Segundo a teoria do agir comunicativo de HABERMAS (1989), um dos pressupostos fundamentais da comunicação não coatada é que os agentes sejam motivados pela veracidade, não mentindo nem intencionalmente nem inconscientemente. Apenas dessa forma torna-se possível o agir comunicativo puro ${ }^{34}$.

$\mathrm{Na}$ esteira do argumento de Jürgen Habermas, é assente que os níveis de democracia hoje dependem dos índices de participação social, publicidade dos atos e conhecimento das informações pelos agentes democráticos. Quando observamos a necessidade de publicidade e veracidade proposicional sobre as informações referentes a um regime ditatorial, mais fortes se mostram os fundamentos da democracia como resultante desta antítese ${ }^{35}$.

A democracia há muito não se faz apenas com a representação da vontade no parlamento. Pelo contrário, a esfera pública cada vez mais adentra o espaço privado dos grupos atuantes, demandando que nessas esferas também sejam garantidos os pressupostos de participação, pluralismo e publicidade (HABERMAS, 1989). Um exemplo é a representatividade das organizações de direitos humanos e de familiares de torturados no espaço público brasileiro, motivando ações políticas e impulsionando o processo de transição para a democracia efetiva.

\footnotetext{
${ }^{31}$ Updated Set of principles for the protection and promotion of human rights through action to combat impunity. Comissão de Direitos Humanos da Organização das Nações Unidas.

${ }^{32}$ Dentre muitas previsões essenciais, destaque seja dado ao direito de petição aos três poderes do estado para defesa de direitos, insculpido no art. 5 XXXIV, $a$, da Constituição Federal, bem como o direito de obter certidões do Poder Público, com informações oficiais sobre interesses pessoas e determinados (art. $5^{\circ}$, XXXIV, $b$, da Constituição Federal).

33 A falseabilidade não deve estar limitadas às informações que contenham dados pessoais, mas quaisquer informações que sejam dotadas de interesse público. De nada adianta a publicidade de atos sem que se garanta a veracidade e a falseabilidade das informações; caso contrário, a publicidade constitui apenas mais uma afirmação de poder, impondo o autoengano de forma heterônoma como forma de controlar o exercício da história e da memória.

${ }^{34}$ HABERMAS (1989) ressalta a existência de 4 "pressupostos da validade" (Geltungsansprüche) da comunicação não coatada: compreensão dos conteúdos comunicados, veracidade dos interlocutores, veracidade dos conteúdos proposicionais e a validade das razões do ato linguístico.

${ }^{35}$ De fato, a comparação de uma realidade democrática com fatos públicos e verdadeiros sobre um regime ditatorial ou autoritário ressalta o ambiente político aos olhos dos interlocutores. A real consciência democrática só pode surgir pelo conhecimento do que seria não democrático, de forma que esta consciência, pautada pelos pressupostos do agir comunicativo, possibilite a participação efetiva no aprimoramento do espaço político.
}

Revista de Direito Brasileira | Florianópolis, SC | v. 23 | n. 9 | p.83-111 |Mai./Ago. 2019 
Estas arenas políticas informais também devem ser dialogicamente discursivas e pautadas pelo agir comunicativo.

A publicidade, portanto, enquanto mandamento de eliminação do segredo público, é fundamento para o direito à verdade. Todavia, o princípio da publicidade é também pelo direito à verdade ressignificado, como pressuposto não apenas de justiça restaurativa, mas também da democracia pautada por um fluxo de comunicações não coatadas ${ }^{36}$.

Nesta linha é que NOHARA (2009) defende a transparência e a abertura para o debate público como a forma de se lançar luz sobre os dilemas fundamentais dos povos latinoamericanos: ditadura versus democracia e alienação versus identidade histórica.

Aliás, trabalhar tais dilemas é também desenterrar grupos políticos informais que vivenciaram o terrorismo de estado e trazê-los de volta à arena política. Tal necessidade ultrapassa a livre criação de partidos assegurada pela Constituição Federal e demanda a construção de memória política em esferas tradicionalmente consideradas privadas (HABERMAS, 1989).

\subsection{O Acesso a Documentos do Regime Militar Brasileiro após a Constituição Federal de 1988}

Com a promulgação da Constituição Federal de 1988 extrai-se da leitura coordenada do art. 37, caput, e do art. 93, IX e X, que devem ser públicos os atos e negócios da Administração ${ }^{37}$, observadas as situações que envolvem segurança nacional ou similar. Mais de dez anos depois, a Lei $\mathrm{n}^{\circ}$ 9.784/1999 veio a regular os procedimentos administrativos, consolidando direitos e deveres do cidadão e da Administração, com diversos princípios e regras no que tange à divulgação de informações e atendimento de demandas ${ }^{38}$.

Entretanto, é difícil responder, em termos operacionais, até que ponto se estende a transparência administrativa e a publicidade dos atos oficiais, mesmo diante desse arcabouço normativo (LEAL, 2012). A materialização da transparência não pode prescindir da conjugação de publicidade e motivação dos atos (JUNIOR, 2004).

Para os fins deste artigo, a publicidade se concretiza através da garantia de acesso aos

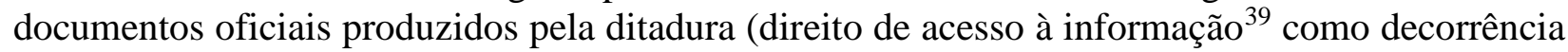
da publicidade). $\mathrm{O}$ franqueamento deste acesso é o primeiro passo na concretização do direito à verdade com todas as suas ressignificações já expostas.

Por óbvio, nem todos os documentos ou informações do estado devem ser públicos e de livre acesso. O próprio texto constitucional excepciona expressamente a hipótese em que o sigilo seja imprescindível à segurança da sociedade e do Estado (art. $5^{\circ}$, inciso XXXIII). Contudo, tal previsão é vaga e deixa ampla margem de interpretação.

Não se esqueça, quanto ao ponto, a experiência internacional, no sentido de que a recusa na divulgação de informações só será justificada, no caso concreto, quando atender ao chamado

\footnotetext{
${ }^{36} \mathrm{O}$ direito à verdade, embora visto inicialmente como mero instrumento de justiça às vítimas e seus familiares para terem também o seu relato contado pela história, passa por ressignificação diante da publicidade na democracia participativa. Dessa forma, o direito à verdade passa a ser de interesse não apenas dos perseguidos e familiares, mas de toda a sociedade, garantindo aprimoramento democrático com base no preenchimento dos requisitos do discurso.

${ }^{37} \mathrm{Na}$ realidade, a leitura de tais dispositivos vai além, no sentido de que além de públicos os atos da Administração devem ser motivados. Tal motivação também deve ser transparente e pública, conforme destaca JUNIOR (2004) em sua obra sobre as relações entre transparência, motivação e publicidade. Entretanto, para o tema deste artigo, é relevante abordar o tratamento da publicidade, sem adentrar no mérito da motivação dos atos administrativos.

${ }^{38}$ Dentre os dispositivos da lei que se relacionam com a temática presente: art. $2^{\circ}$, parágrafo único, incisos $\mathrm{V}$ e IX (divulgação de atos e utilização de formas simples que possibilitem adequado grau de certeza), art. $3^{\circ}$, inciso II (direito do cidadão de ter acesso a procedimento administrativo) e art. $4^{\circ}$, inciso I (dever do cidadão de expor os fatos conforme a verdade), dentre outros.

${ }^{39} \mathrm{O}$ direito de acesso à informação é expressamente previsto no art. $5^{\circ}$, inciso XXXIII, da Constituição Federal. Os componentes deste direito serão expostos de maneira mais aprofundada no ponto 2.1, infra.
}

Revista de Direito Brasileira | Florianópolis, SC | v. 23 | n. 9 | p. 83-111 |Mai./Ago. 2019 
teste de três fases (LEAL, 2012). Paula Ligia MARTINS (2011) explana que tal teste da jurisprudência internacional consiste em uma avaliação da relação custo (dano) e benefício (interesse público) na divulgação, ou seja, uma verificação da proporcionalidade do sigilo através de uma ponderação dos valores envolvidos ${ }^{40}$.

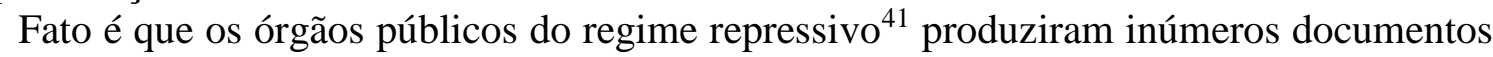
relativos a seus atos e a pessoas que passar pelos órgãos, desde sua prisão, depoimentos e destino final. Tal fato pode ser explicado pela grande burocratização da organização militar, mas também pela necessidade de se guardar dados para orientar a execução de novas operações repressivas (BAUER, 2006).

KONRAD e LOPES (2013) destacam como as informações produzidas nos diversos países da América do Sul formaram uma grande rede de informações que eram trocadas entre vizinhos, buscando conter os inúmeros exílios nos países fronteiriços. Dessa maneira, os arquivos de repressão encontram-se não apenas no interior dos órgãos militares, mas até mesmo além de nossas fronteiras, enredando os países do Cone Sul em um momento político semelhante.

O Brasil possui um volume precioso de acervos documentais constituídos pelo Estado durante períodos autoritários. São os arquivos das polícias políticas que, desde os anos de 1910, acumularam um impressionante testemunho de como o Estado brasileiro desmontou opositores e impôs violência no espaço público. Essa posição de destaque pode ser exemplificada pelo volume de documentos públicos produzidos e acumulados pelos órgãos integrantes do extinto Sistema Nacional de Informações e Contrainformação (SISNI), que tinha por órgão central o extinto Serviço Nacional de Informações (SNI). De acordo com dados do Arquivo Nacional, apenas o acervo desta instituição sobre o período militar é composto por aproximadamente dezesseis milhões de páginas de textos, além de outros tipos documentais (RODRIGUES, 2014).

A regulamentação do acesso a documentos públicos, mesmo após a Constituição Federal de 1988, optou por privilegiar, desde o início, o sigilo sobre os documentos militares ${ }^{42}$.

A primeira regulamentação do acesso a documentos públicos surgiu com a Lei de Arquivos (Lei $\mathrm{n}^{\mathbf{0}} 8.159$ de 1991). Apesar da demagogia da lei em ampliar o acesso aos documentos públicos, acabaram por ser excluídos de seu alcance os arquivos das Forças Armadas com a edição do Decreto $n^{\circ} 99.347$ de $1990^{43}$. Aqui, restou impossibilitado o acesso aos documentos de repressão.

Em 1995, foi publicada a Lei $\mathrm{n}^{\circ}$ 9.140, que veio reconhecer como mortas pessoas desaparecidas durante o regime militar e estabeleceu a política de reparação, pilar da justiça transicional. Entretanto, ao mesmo tempo que tal porta se abriu, as outras estavam fechadas, pois era impedido o acesso a documentos que comprovassem a perseguição para fins de obter a devida reparação.

\footnotetext{
${ }^{40}$ Segundo o teste de três fases, a confidencialidade em um dado documento ou situação concreta só pode ser considerada legítima se presentes os seguintes requisitos: a informação solicitada relaciona-se a um dos objetivos legítimos para restrição do acesso à informação, que devem estar obrigatoriamente contidos em lei; a divulgação daquela informação poderá concretamente causar danos conforme a previsão normativa; e o prejuízo deve ser maior do que o interesse público na liberação da informação específica (MARTINS, 2011).

${ }^{41}$ A produção em massa de documentos do regime ditatorial não é exclusividade do Brasil; pelo contrário, pode ser considerada uma caraterística comum às ditaduras militarizadas. BAUER (2006) aponta, como exemplo, as semelhanças quanto ao ponto com a Argentina.

${ }^{42}$ Dessa forma, ao contrário do teste de ponderação (teste de três fases) já exposto e adotado ao redor do mundo, a regulamentação brasileira criou uma presunção absoluta de sigilo, dificultando e impedindo o acesso a quaisquer documentos sob a justificativa de "segurança nacional".

${ }^{43}$ Esse Decreto, na realidade, alterou o Decreto $\mathrm{n}^{\circ} 79.099$ de 1977 , incluindo no rol de autoridades que podem decretar sigilo máximo todos os chefes das Forças Armadas. O efeito disso é que todos os documentos do regime em poder destas autoridades foram decretados como ultrassecretos, em violação ao instituto basilar da justiça de transição que demanda o afastamento das posições de poder de todas as autoridades perpetradoras de violação aos direitos humanos (vertente da reforma institucional).
} 
Em agravamento da situação, no apagar das luzes do governo $\mathrm{FHC}$, foi publicado o Decreto $n^{\circ} 4.553$, que trouxe a possibilidade de atribuição de sigilo eterno a documentos ${ }^{44}$. Em 2003, contudo, acirraram-se as disputas em torno da Guerrilha do Araguaia, culminando com a decisão da justiça federal do Distrito Federal que determinou a quebra de sigilo sobre a operação $^{45}$. Em face dessa decisão, o governo Lula promulgou ainda em 2003 o Decreto $n^{\circ} 4.850$, instituindo comissão interministerial mista para obter informações relativas à operação e lhe conferiu acesso a documentos. Contudo, mais uma vez o acesso não foi facultado amplamente aos cidadãos.

Em 2005, foi sancionada a Lei $n n^{\circ} 11.111$, que veio regulamentar, pela primeira vez, o direito constitucional de acesso à informação. Todavia, a lei manteve a possibilidade de estabelecimento de sigilo infinito a critério de órgão da Presidência da República ${ }^{46}$

Em razão de enorme pressão exercida por entidades internacionais de Direitos Humanos, foi publicado, ainda em 2005, o Decreto $\mathrm{n}^{\mathrm{o}}$ 5.584, determinando que diversos arquivos da repressão ${ }^{47}$ fossem transferidos e concentrados no Arquivo Nacional. Contraditoriamente, ressalvou do acesso todos os documentos que pudessem causar prejuízos à segurança da sociedade e do estado.

Por todo esse breve histórico é que se pode afirmar que a atual Lei de Acesso à Informação (Lei $\mathrm{n}^{\circ}$ 12.527/2011) é a primeira regulamentação a trazer, efetivamente, a publicidade como regra e o sigilo como exceção (KONRAD, LOPES, 2013).

Tanto o governo FHC como o governo Lula promulgaram decretos, medidas provisórias ou leis que estenderam, indefinidamente, o prazo de sigilo dos documentos oficiais considerados prejudiciais à sociedade ou ao Estado. Ao mesmo tempo, criaram ou fortaleceram a Secretaria Especial de Direitos Humanos, a Comissão Especial sobre Mortos e Desaparecidos Políticos e a Comissão de Anistia, que têm trabalhado para estabelecer medidas administrativas e reparatórias de "justiça de transição" (SANTOS, 2010). A contradição é mais do que aparente: demonstra a ausência de medidas de transição definidas e eficazes.

A insistência dos governos brasileiros, após a abertura política até os dias atuais (de certa forma), em manter como sigilosos documentos e informações relativos à ditadura militar, atinge diretamente não apenas o direito da família de vítimas políticas de poderem dar enterro digno aos seus entes e conhecer as circunstâncias de suas mortes, mas também o direito da sociedade brasileira de ter acesso à verdade sobre sua história recente ${ }^{48}$ (NOHARA, 2009).

Com base nessa constatação, o Supremo Tribunal Federal declarou, já em 2006, que o simples conhecimento histórico, ainda que para fins privados e não declarados, constitui motivo legítimo para garantir o acesso aos documentos, ou seja, o interesse social deve prevalecer sobre o mero sigilo administrativo ${ }^{49}$.

\footnotetext{
${ }^{44}$ A legislação previa o prazo de 30 anos para a duração do sigilo (art. 23 da Lei no 8.159 de 1991). Contudo, o art. $7^{\circ}$ do Decreto $\mathrm{n}^{\circ} 4.553$ de 2002 trouxe o sigilo de até 50 anos, com a possibilidade de prorrogações indefinidas, o que, trocando em miúdos, equivale a possibilitar o sigilo eterno.

${ }^{45}$ A sentença foi proferida pela juíza Solange Salgado no processo no 82.00.24682-5, que havia sido iniciado em 1980. A juíza deu prazo de 120 dias para a União Federal informar onde estão sepultados os restos mortais dos familiares dos 22 autores do processo.

${ }^{46}$ A referida previsão estava contida no art. $6^{\circ}, \S 2^{\circ}$, da Lei no 11.111 de 2005.

${ }^{47}$ Mais especificamente, o Decreto determinou a transferência dos arquivos dos extintos Conselho de Segurança Nacional (CSN), Comissão Geral de Investigações (CGI) e do Serviço Nacional de Informações (SNI) que estavam de posse da Agência Brasileira de Inteligência (ABIN).

${ }^{48}$ Indiretamente, como já frisado em outro momento, o sigilo e a falta de verdade impedem o pleno desenvolvimento de cidadania e a consolidação de práticas e modelos democráticos de gestão.

${ }^{49}$ EMENTA: RECURSO EM MANDADO DE SEGURANÇA. SUPERIOR TRIBUNAL MILITAR. CÓPIA DE PROCESSOS E DOS ÁUDIOS DE SESSÕES. FONTE HISTÓRICA PARA OBRA LITERÁRIA. ÂMBITO DE PROTEÇÃO DO DIREITO À INFORMAÇÃO (ART. $5^{\circ}$, XIV DA CONSTITUIÇÃO FEDERAL). 1. Não se cogita da violação de direitos previstos no Estatuto da Ordem dos Advogados do Brasil (art. $7^{\circ}$, XIII, XIV e XV da L. 8.906/96), uma vez que os impetrantes não requisitaram acesso às fontes documentais e fonográficas no exercício da Revista de Direito Brasileira | Florianópolis, SC | v. 23 | n. 9 | p. 83-111 |Mai./Ago. 2019
} 
Na realidade, como já frisado em momento anterior, é raro o documento que não irá conter uma mentira ou distorção, atribuídas às autoridades repressivas que produziram o arquivo (GREEN, 2011).

Entretanto, a possibilidade duvidar e questionar os arquivos, como uma instituição com tensões e lutas, significa restituir-lhes o caráter histórico e cultural e perceber seu caráter de espaços complexos que devem ser apreendidos como objetos de reflexão, e não mera imposição, a partir de problemas e pontos de vista (CATELA, 2011).

Com base nessas reflexões de GREEN e CATELA, pretendemos agora analisar a possibilidade de construção de memória histórica e a importância das Comissões de Verdade nesse sentido.

\subsection{A Construção da Memória Histórica e a Comissão Nacional da Verdade}

O uso do direito deve servir, sob a ótica da justiça de transição, para reconstruir a memória política. A reiterada reformulação do objeto da disputa implica uma constante reconstrução da própria memória política ${ }^{50}$ (SANTOS, 2010).

É notório o papel de destaque exercido pelas chamadas Comissões de Verdade na reconstrução dessa memória. Trata-se de órgãos de investigação criados para ajudar as sociedades na confrontação crítica de seu passado ${ }^{51}$. Segundo CUYA (2011), existem quatro contribuições fundamentais das Comissões de Verdade no espaço sul-americano: o autodescobrimento de uma realidade até então ignorada, a identificação dos setores envolvidos na criação desta, a personalização e humanização das vítimas de perseguições e a reparação possível dos danos causados ${ }^{52}$.

Para PERLINGEIRO (2015), existem dois requisitos fundamentais para o bom funcionamento de uma Comissão de Verdade: a independência dos seus membros e a expressa

função advocatícia, mas como pesquisadores. 2. A publicidade e o direito à informação não podem ser restringidos com base em atos de natureza discricionária, salvo quando justificados, em casos excepcionais, para a defesa da honra, da imagem e da intimidade de terceiros ou quando a medida for essencial para a proteção do interesse público. 3. A coleta de dados históricos a partir de documentos públicos e registros fonográficos, mesmo que para fins particulares, constitui-se em motivação legítima a garantir o acesso a tais informações. 4. No caso, tratava-se da busca por fontes a subsidiar elaboração de livro (em homenagem a advogados defensores de acusados de crimes políticos durante determinada época) a partir dos registros documentais e fonográficos de sessões de julgamento público. 5. Não configuração de situação excepcional a limitar a incidência da publicidade dos documentos públicos (arts. 23 e 24 da L. 8.159/91) e do direito à informação. Recurso ordinário provido. (RMS 23036, Relator (a): Min. MAURÍCIO CORRÊA, Relator p/ Acórdão: Min. NELSON JOBIM, Segunda Turma, julgado em 28/03/2006)

${ }^{50}$ A autora usa como exemplo o caso da Guerrilha do Araguaia, em que os autores das inúmeras ações pretendem ver reconhecidos o seu direito ao resgate da história e da memória das vítimas políticas. Até mesmo a morosidade da justiça é utilizada pela autora como um instrumento do reavivamento da memória, pois a via judicial é apenas subsidiária da mobilização política, enquanto a morosidade constitui novo mecanismo de aquecimento da atuação humanitária, redirecionando continuamente o objeto da atuação política (SANTOS, 2010).

51 A criação das Comissões de Verdade teria origem na atuação direta do Tribunal Ético Internacional, também chamado de Tribunal Russel, cuja atividade veio a ser, posteriormente desempenhada pelo Tribunal Permanente dos Povos (TPP). A atuação destes órgãos favoreceu a criação de redes de familiares de vítimas buscando verdade e reparação, cuja visibilidade demandou atuação pública, dando origem às referidas comissões (CUYA, 2011). Na Argentina, a Comissão de Verdade (CONADEP) foi criada já em 1983, ou seja, no mesmo ano em que cessou a ditadura. Notório, portanto, o atraso brasileiro na atuação quanto ao ponto, uma vez que nossa Comissão Nacional da Verdade veio a ser criada apenas em 2012, mais de 20 anos após a redemocratização.

${ }^{52}$ A reparação dos danos causados não inclui apenas a indenização das vítimas de familiar, papel que já vinha sendo desempenhado por comissões especiais no Brasil desde 1995. Na realidade, a reparação dos danos inclui a reparação política, com a formulação e a recomendação de novas linhas de atuação baseadas nos fatos e documentos descobertos pela comissão.

Revista de Direito Brasileira | Florianópolis, SC | v. 23 | n. 9 | p.83-111 |Mai./Ago. 2019 
previsão de situações de sigilo sem caráter de generalidade ${ }^{53}$. A independência, segundo o autor, só pode ser alcançada com a garantia de autonomia administrativa e financeira, a inamovibilidade dos membros e o pagamento de remuneração justa.

Com esse fim, o Comitê de Direitos Humanos da ONU orienta que as comissões de investigação, inclusive as de caráter internacional, devem respeitar as seguintes diretrizes: a) formar-se segundo critérios que demonstrem à opinião pública a competência em direitos humanos e a imparcialidade dos seus membros, dentre os quais devem estar especialistas em direitos humanos; b) seus membros devem se beneficiar dos privilégios e imunidades necessários à sua proteção e à proteção de suas atividades, inclusive após o término de sua missão, sobretudo, com relação a toda ação difamatória ou qualquer outra ação civil ou penal motivada pela simples investigação; c) garantir representação adequada das mulheres e de outros grupos com maior vulnerabilidade à violações de direitos humanos.

É notório, todavia, que nenhuma das comissões de verdade da América Latina tenha efetivamente ostentado todo este conjunto de prerrogativas (PERLINGEIRO, 2015).

Quanto à atuação de tais comissões e a forma de realização de suas investigações, é importante garantir que as comunidades de violência tenham amplo grau de representatividade nos procedimentos e que a informação gerada tenha suficiente grau de qualidade, clareza e publicidade $^{54}$ (SIMON, 2011). Ainda mais importante, todavia, é atentar-se ao fato de que as investigações envolvem condutas de natureza criminal, razão pela qual devem ser respeitados os direitos e garantias individuais de todos os investigados, mormente quando se opta por tornar pública a responsabilidade individual ${ }^{55}$. Dessa forma, devem ser observados direitos constitucionais à ampla defesa (que inclui a assistência por advogado), ao silêncio e a não autoincriminação.

É imperioso, ainda, que se leve em conta os vários processos na produção de história, inclusive a documental. Primeiramente, nem todos os fatos estão efetivamente documentados; ademais, a criação de arquivos também serve ao propósito de silenciar o passado, pois a decisão sobre a conservação dos arquivos é, de certa forma, arbitrária. De certa forma, a doutrina (LEAL, 2012) destaca que selecionar fatos e lançar em documentos ou arquivos é uma decisão política e que tal decisão influenciará o tipo de história produzida ${ }^{56}$. O trabalho das Comissões deve ter a consciência de tais vicissitudes do discurso histórico ao atentar o conhecimento de uma "versão alternativa".

Os debates sobre a Comissão da Verdade, no Brasil, suscitaram a questão de que os "dois lados" deveriam ser investigados ${ }^{57}$. Carlos FICO (2012) ressalta que esse argumento pode

\footnotetext{
${ }^{53}$ Nesse sentido são criticadas todas as previsões genéricas de sigilo, expressas normalmente sob as cláusulas de segurança do Estado ou interesse nacional. Tais previsões genéricas eram a regra no direito brasileiro até a promulgação da nova Lei de Acesso à Informação, como se verá em seguida.

${ }^{54}$ A qualidade da informação produzida deve ser aferida pelo real conhecimento proporcionado à sociedade acerca das violações de direitos humanos e da extensão da responsabilidade do Estado e de suas falhas (SIMON, 2011). Não se trata, portanto, de criar polêmicas e acusações midiáticas com base nas informações colhidas, mas de proporcionar debate maduro que seja apto a alcançar a discussão pública.

${ }^{55}$ SIMON (2011) destaca a possibilidade conferida à Comissão Nacional da Verdade brasileira de indicar nomes dos perpetradores das violações, especificando e individualizando condutas. Em face dessa constatação, defendeu o autor a necessidade de que os interrogatórios respeitassem as garantias processuais penais de produção da prova, dentre as quais o direito à defesa técnica e ao silêncio. Com base nas colocações do autor, pode-se considerar triunfante a Comissão brasileira, pois garantiu o mais amplo direito de defesa aos investigados e evitou transformar a divulgação de nomes e responsabilidade em uma polêmica midiática.

${ }^{56}$ Reiteramos, aqui, a advertência de GREEN (2011) de que os documentos da repressão são repletos de mentira, razão pela qual o acesso e a leitura devem ser feitos já com essa consciência. Entretanto, para LEAL (2012) tal circunstância apenas corrobora a necessidade de amplo acesso aos documentos, como forma de confronto da versão oficial.

${ }^{57}$ É a mesma tese que, na Espanha, é chamada de "equivalência" e, na Argentina, de "dos demônios", isto é, a violência da repressão comparar-se-ia à violência da esquerda

Revista de Direito Brasileira | Florianópolis, SC | v. 23 | n. 9 | p. 83-111 |Mai./Ago. 2019
} 
parecer sóbrio à primeira vista, mas esconde uma falácia: as comissões da verdade são criadas para apurar crimes cometidos pelo Estado, não por pessoas ${ }^{58}$. Mais importante é frisar que o Estado brasileiro, mesmo durante o regime autoritário, poderia ter combatido a luta armada sem apelar para a tortura e o extermínio. Além disso, muitos ex-integrantes da luta armada - ao menos os que sobreviveram - já foram julgados e punidos (FICO, 2012).

Por essas razões é que exigir um processo de estabelecimento da verdade sobre a ditadura não é "revanchismo". Irene NOHARA (2009) destaca que a sociedade brasileira não poderá evitar e repudiar práticas autoritárias se não reconhecer a dívida para com os que sofreram tortura e perseguição ${ }^{59}$.

De fato, FICO (2012) destaca que uma das principais peculiaridades da chamada "História do Tempo Presente" é a constante pressão e coação das pessoas que viveram o próprio período histórico. Por outro lado, todo o suposto conhecimento pode ser confrontado pelo testemunho das pessoas que viveram os próprios fatos.

Dessa forma, torna-se cínico contrapor-se a alguém que, em defesa de sua posição, argumenta que foi torturado (TORELLY, 2012). Os eventos traumáticos podem se tornar quase infindáveis, justamente por sua constante reelaboração através do exercício da memória. $\mathrm{O}$ conceito de memória diferencia-se da história justamente por ser produzido "de dentro", ou seja, pelos próprios partícipes do evento (CATELA, 2011).

A memória dos eventos integra, inevitavelmente, qualquer esforço de construção da história. Na História do Tempo Presente, portanto, não há contraposição entre memória e história, mas uma complementariedade, ou melhor uma imbricação constituinte (FICO, 2012). Portanto, a investigação pelas Comissões de Verdade e o direito à verdade não buscam a substituição da narrativa oficial da repressão,

mas sim a viabilização de insurgência de narrativas plurais construídas com igualdade de oportunidades, ou seja, com igual acesso às 'fontes de verdade' e meios de difusão. O caso brasileiro é latente nesse sentido, uma vez que as narrativas derivadas da narrativa oficial seguem sendo atualizadas, com acesso privilegiado a fontes ${ }^{60}$, enquanto se procurou negar igual possibilidade às vítimas, tratadas como 'revanchistas' ao tentarem trazer a público suas versões (TORELLY, 2012, p. 269)

O direito à memória configura justamente a inserção dessas múltiplas verdades no seio social e na construção da história. $\mathrm{O}$ direito à memória é que torna operacional o elo que liga o passado ao futuro (ARENDT, 2003). Esse exercício de memória cumpre duas funções: repara a dignidade política das vítimas e agrega um grande número de reflexões sobre a experiência autoritária, permitindo a autoconsciência histórica ${ }^{61}$ (TORELY, 2012).

Nesse sentido, o PNDH3, em 2009, trouxe diversas diretrizes sobre o direito à memória, pela primeira vez. A ação $c$ da diretriz 25, por exemplo, proíbe que logradouros e prédios

\footnotetext{
58 De fato, a Comissão da Verdade Brasileira pôde indicar, nominal e individualizadamente, os nomes dos perpetradores das violações de direitos humanos. Todavia, não tem competência para realizar a persecução criminal contra os indivíduos, nem é esta sua finalidade.

${ }^{59}$ A autora ressalta ainda que pacificação com ocultamento não pode ser considerada pacificação, pois a paz é fruto da justiça e não do esquecimento (NOHARA, 2009).

${ }^{60}$ Aqui o autor faz referências às versões produzidas por próprios membros dos grupos de repressão, que seguem sendo atualizadas, como a publicação do livro do coronel Ustra (A Verdade Sufocada), em 2007.

${ }^{61}$ A esse respeito foram tomadas diversas medidas, mesmo antes da Comissão da Verdade e da nova Lei de Acesso a Informação. Por exemplo, o Programa Nacional de Direitos Humanos 3 (PNDH3), em 2009, trouxe, pela primeira vez, diversas diretrizes sobre o direito à memória. A ação $c$ da diretriz 25 possui dispositivo interessante que proíbe que logradouros ou prédios públicos recebam o nome de pessoas que cometeram crimes de lesa-humanidade. Semelhante disposição consta da Lei Histórica Espanhola, promulgada após o fim do regime franquista.
} 
públicos recebam o nome de pessoas que cometeram crimes de lesa-humanidade, no mesmo sentido da Lei Histórica Espanhola.

\section{A ABERTURA DA LEI DE ACESSO À INFORMAÇÃO E OS DESAFIOS REMANESCENTES DE ACESSO A ARQUIVOS}

Nesse capítulo, pretende-se demonstrar que o impulso da justiça de transição, exposto no capítulo anterior, auxiliou na ressignificação de institutos do direito administrativo, em especial o direito de acesso à informação e aos documentos oficiais.

A Lei de Liberdade de Imprensa suíça, de 1766, é tida como a primeira lei a tratar especificamente sobre a natureza pública dos documentos oficiais, assegurando a todo indivíduo o direito de acessá-los, salvo aqueles classificados como secretos ${ }^{62}$. No âmbito da América Latina, a primeira regulamentação veio na Colômbia, 1888 (JUNIOR, 2015).

Na América Latina, dos 20 Estados existentes, pelo menos 11 já contêm normas gerais sobre o direito de acesso à informação ${ }^{63}$. Assim tem se comportado as Constituições de parte significativa dos países Ocidentais, uma vez que pelo menos 60 países protegem tal direito. Em outros, apesar de não estar explícito no texto constitucional, foi reconhecido como direito implícito pelas respectivas Supremas Cortes, como é o caso de Argentina, Canadá e França, por exemplo.

Em seguida, serão analisados os componentes principais do direito à informação, bem como o contexto de inauguração da Lei $n^{\circ} 12.527 / 2011$, que ressignificou tal instituto no direito brasileiro. Por fim, demonstraremos como as modificações trazidas pela legislação criou uma "onda de publicização" de arquivos da repressão, auxiliando na tarefa de reconstrução da memória.

\subsection{Os Componentes de um Direito Fundamental à Informação}

O Direito à Informação é considerado um direito fundamental de quarta geração, ao lado do direito à democracia e ao pluralismo.

ALDER (2002) explicita que, além do clamor pela liberdade os argumentos em favor do que chama de "governo aberto" incluem o fortalecimento da democracia com base em uma opinião pública bem informada, a autonomia do eleitor, a participação direta na formulação de políticas públicas e o aumento da confiança do público no governo.

Em nossa Constituição Federal, sua fonte imediata encontra-se no art. $5^{\circ}$, incisos XIV ${ }^{64}$ e XXXIII ${ }^{65}$, já referidos. Entretanto, pode ser encontrado indiretamente em outros dispositivos, como o art. 37, inciso II ("o acesso dos usuários a registros administrativos e a informações sobre atos de governo, observado o disposto no art. 5', X e XXXIII") e o art. 216, § $2^{\circ}$ ("Cabem à administração pública, na forma da lei, a gestão da documentação governamental e as providências para franquear sua consulta a quantos dela necessitem").

\footnotetext{
${ }^{62}$ Existem registros esparsos antigos, como a necessidade de prestação de contas pelos governantes, especialmente prevista na Declaração dos Direitos do Homem e do Cidadão de 1789 (arts. 11, 14 e 15). Contudo, nenhum desses registros trata, especificamente, do acesso à documentos públicos (JUNIOR, 2015).

${ }^{63}$ Nestes países consultados, há previsão expressa no texto constitucional: Brasil,Chile, Colômbia, Costa Rica, Equador, México, Nicarágua, Panamá, Paraguai, Peru e Venezuela.

${ }^{64}$ Art. $5^{\circ}$, XIV - é assegurado a todos o acesso à informação e resguardado o sigilo da fonte, quando necessário ao exercício profissional.

${ }^{65}$ Art. $5^{\circ}$, XXXIII - todos têm direito a receber dos órgãos públicos informações de seu interesse particular, ou de interesse coletivo ou geral, que serão prestadas no prazo da lei, sob pena de responsabilidade, ressalvadas aquelas cujo sigilo seja imprescindível à segurança da sociedade e do Estado.
}

Revista de Direito Brasileira | Florianópolis, SC | v. 23 | n. 9 | p. 83-111 |Mai./Ago. 2019 
Em 2008, foi aprovada pelo Comitê Jurídico Interamericano (CJI) da Organização dos Estados Americanos (OEA) uma série de princípios sobre o direito de acesso à informação, dentre os quais: 1. Em princípio, toda informação é acessível; 2. O acesso a informação se estende a todos os órgãos públicos e entes privados com recursos públicos; 3 . O direito de acesso a informação se dirige a toda informação; 4. Os órgãos públicos devem difundir informação sobre suas funções e atividades; 5. Devem ser implementadas regras claras, justas, não discriminatórias e simples referente a requerimentos de informação; 6 . As exceções do direito de acesso à informação devem ser estabelecidas por lei; 7. O ônus de prova para justificar qualquer negativa de acesso à informação deve recair sobre o órgão público; 8. Todo indivíduo deve ter o direito de recorrer contra qualquer negativa ou obstrução de acesso à informação; 9. Toda pessoa que intencionalmente negue ou obstrua o acesso à informação, violando as regras que garantem esse direito, deve estar sujeita a sanção; 10. Devem ser adotadas medidas de promoção e implementação do direito de acesso à informação (PERLINGEIRO, DÍAZ, LIANI, 2016).

$\mathrm{O}$ estudo mais completo do direito de acesso à informação na América Latina pode ser encontrado no trabalho de Toby MENDEL (1999), que buscou sistematizar os traços essenciais de tal direito face suas diversas regulamentações. O autor indica nove "princípios" para a compreensão do direito fundamental: transparência máxima, obrigação de publicar, promoção de governo aberto, exceções limitadas, processo de facilitação do acesso, custos reduzidos, governo com reuniões abertas, precedência da transparência ${ }^{66}$ e proteção para denunciantes.

Desses princípios podem ser extraídas diversas imbricações que não são tão claras a uma primeira leitura. Inicialmente, observa-se que a garantia de acesso à informação é oponível a todo o Poder Público, incluindo autoridades administrativas, legisladores e tribunais. Entretanto, também devem estar vinculadas as pessoas privadas que, em regime de direito público, exercem funções públicas e, ainda, aquelas que, ainda que em regime de direito privado, atuam em prol da administração pública. Deve-se ter em mente que o direito administrativo não pode permitir uma "fuga" para o direito privado ${ }^{67}$ (WOLF, 2006).

Estabelecendo a visão do acesso à informação como direito fundamental, é necessário analisar a possibilidade de limitação deste direito e os limites dos seus limites (Schränken der Schränken). Toda e qualquer limitação do direito de acesso à informação (em outras palavras, o sigilo) deve estar contida em lei em sentido estrito. Aliás, trata-se de tema em relação ao qual a discricionariedade administrativa deve ser reduzida (WOLF, 2006), mediante a utilização de formas legislativas precisas e específicas.

A concepção de direito à informação como direito fundamental refuta, portanto, o uso de construções legislativas "interesse público", "segurança do Estado" ou "proteção à privacidade" para justificar a atribuição de sigilo ${ }^{68}$.

Esta concepção não é meramente doutrinária, mas encontra esteio na jurisprudência do Supremo Tribunal Federal. No voto-vencedor do RMS 23.036/2006, o Pretório Excelso assentou:

\footnotetext{
${ }^{66}$ A precedência da transparência, segundo MENDEL (1999), indica que o acesso à informação e a transparência devem preceder a qualquer legislação que estabeleça sigilo, ou seja, devem ser revisadas todas as leis que restringem a divulgação de informações para que sejam adequadas ao direito de acesso.

${ }^{67}$ Tal imputação de dever refoge à visão meramente orgânica ou subjetiva da administração pública, focando em um critério objetivo para atribuir a rubrica de Administração Pública às atividades do estado destinadas à satisfação concreta dos interesses públicos e coletivos. Todas estas atividades estariam sujeitas ao regime público e à garantia de acesso à informação, ainda que prestadas por pessoas privadas. Também a concepção de Otto Mayer, focada nas relações jurídicas entre Estado e particular com esteio na soberania e nas prerrogativas públicas, o que permite aplicar "deveres públicos" a qualquer ente que faça uso das prerrogativas estatais.

${ }^{68}$ Tais estruturas, todavia, estão contidas em nossa Constituição Federal e também na Lei Modelo Interamericana de Acesso à Informação. Todavia, cabem a estas normas traçar parâmetros genéricos, enquanto deve a lei ordinária delimitar, faticamente, o que se entende por "segurança do estado" ou "interesse público", e não apenas repetir as expressões como vinha sendo feito na legislação brasileira até a edição da Lei n ${ }^{\circ}$ 12.527/2011.
} 
Quando se trata do direito à informação não há espaço para a discricionariedade. Da mesma forma, não se pode dar a uma norma interpretação ampliativa para restringir um direito fundamental, restrição essa que não se pautaria em nenhum princípio constitucional de mesmo valor em nosso ordenamento. $\mathrm{O}$ direito fundamental à informação, diante de nossa história recente, é talvez um dos mais caros no elenco do art. $5^{\circ}$ da Constituição ${ }^{69}$ (RMS 23.036, STF, 2006, p. 280).

As hipóteses de sigilo nas quais irão se materializar as máximas do "interesse público", da "segurança do Estado" e da "proteção à privacidade" devem estar precisamente definidas em lei, a qual também deve conter as limitações de tais limites.

Um dos mais relevantes limites que se estabelece à possibilidade de sigilo resguarda os documentos que digam respeito à ofensa grave aos direitos humanos. Nesta situação, identifica-se o interesse público prevalente através do método da ponderação (WOLF, 2006), o que se aplica não apenas à proteção de direitos humanos, mas também ao exercício de direitos fundamentais ou outro interesse prevalente. Também a máxima da proteção à privacidade encontra limites, como na necessidade de investigação de fatos criminais imputáveis ao indivíduo referido no documento $^{70}$

Por fim, mas não menos importantes, a doutrina destaca as garantias acessórias de proteção ao direito de acesso à informação, como o direito de petição e resposta fundamentada, a possibilidade de requerimento anônimo e sem justificativa, o direito de recorrer das negativas, a divulgação proativa ${ }^{71}$ e a presença de autoridades independentes e imparciais.

Acerca deste último aspecto, identifica-se a tendência, ainda que inicial, de criação de órgãos independentes sobre o acesso à informação, com prerrogativas asseguradas em lei. $\mathrm{O}$ maior exemplo é o órgão instalado no México (Instituto Federal de Acesso à Informação), mas podemos citar ainda os exemplos de Honduras, El Salvador e Chile ${ }^{72}$ (PERLINGEIRO, DÍAZ, LIANI, 2016).

No common law, é notória a preferência por argumentos que privilegiam o sigilo e restringem as opções do público ao acesso de documentos oficiais. Tal realidade acirra-se com as demandas por combate ao terrorismo e a desconfiança generalizada causada pela infiltração de forças estrangeiras no eixo Estados Unidos - Reino Unido.

Em geral, os argumentos levantados em favor do amplo acesso à informação, nestes países, contêm premissas genéricas relacionadas à democracia e participação popular, enquanto o sigilo encontra-se fundamentado em teses aparentemente de maior tangibilidade e objetividade, voltadas à eficiência administrativa e combate ao terrorismo e à criminalidade ${ }^{73}$ (ALDER, 2002).

\footnotetext{
${ }^{69}$ Nessa ocasião, a Corte determinou que o Superior Tribunal Militar (STM) franqueasse o acesso a todos os documentos referentes ao período da repressão, sob o fundamento no interesse público de seu conhecimento. Dessa forma, assegurou, em tese, a publicidade dos arquivos de repressão, o que continuou sendo descumprido pela Corte Militar, como demonstra recente decisão do STF em 2017.

${ }^{70}$ A Lei Modelo Interamericana prevê 4 exceções à proteção do direito à privacidade: o consentimento prévio do interessado, a informação evidentemente pública, o documento relativo à função de empregado público e, por fim, o transcurso de 20 anos do falecimento do interessado.

71 A divulgação proativa envolve a necessidade de que o Estado divulgue, por conta própria e sem requerimento, informações relevantes acerca do desempenho de suas funções e atividades.

${ }^{72}$ A legislação brasileira não seguiu esta tendência, deixando de criar órgão independente na estrutura administrativa a fim de tratar o acesso à informação. Este tem sido um dos pontos de maior crítica em nossa legislação, como irá ser demonstrado no ponto 2.3, infra.

73 ALDER (2002) pontua que o sigilo assenta-se, primariamente, nas postulações de eficiência administrativa: o prejuízo que pode ser causado pela divulgação de certas informações, como as relacionadas à segurança nacional, prevenção de crimes e informações econômicas de alta relevância, inclusive com o possível pânico social. Ademais, argumentos relacionados ao atraso administrativo e aos enormes custos da liberação de informações. É interessante, ainda, o argumento referido pelo autor de que a crítica excessiva após a publicidade prematura pode inibir a implantação de determinadas políticas públicas.
}

Revista de Direito Brasileira | Florianópolis, SC | v. 23 | n. 9 | p. 83-111 |Mai./Ago. 2019 
A nosso ver, o debate depende das lentes que são usadas para enxergar a questão. Obviamente, documentos sensíveis sobre guerra, combate ao terrorismo e segurança de fronteiras, por exemplo, possuem seu sigilo notoriamente justificado, sob o fundamento da segurança nacional. Todavia, este argumento não pode servir de salvo-conduto para classificar todo e qualquer documento como sigiloso, mormente quando se trata de documento histórico cujo debate se faz necessário.

Considerando o contexto em que foi promulgada a Lei $\mathrm{n}^{\mathrm{o}} 12.527 / 2011$ e os seus dispositivos modernizadores do direito de acesso à informação no Brasil, poderemos constatar a facilitação do acesso aos arquivos da repressão e compreender a circularidade entre as medidas de transição e outros ramos do direito.

\subsection{O Contexto da Inauguração da Lei no $\mathbf{n}^{0}$ 12.527/2011}

A aprovação da Lei $n^{\circ} 12.527 / 2011$ coroa um longo processo de lutas contra o excesso de sigilo na esfera governamental que se iniciou muitos anos atrás, antes ainda do fim da ditadura militar, como já exposto no item 1.3, supra. O tema sempre envolveu questões que ultrapassam o campo meramente histórico, pois interessava o cidadão em geral e as vítimas do regime militar que necessitam de documentos outrora sigilosos para fundamentar pedidos de anistia ou de reparação com base na Lei n ${ }^{\circ}$ 9.140/1995, também já referida.

Os "arquivos sensíveis" da ditadura (FICO, 2012) sempre foram alvo de intensas disputas principalmente pela alegada privacidade dos ditadores, o que não era diferente no momento em que editada a legislação em debate.

Em 2009, o governo federal havia criado o projeto "Memórias Reveladas", no Arquivo Nacional, justamente com o propósito de divulgar informações sobre a história política recente do Brasil. A Comissão de Altos Estudos recomendou aos entes estaduais que adotassem o procedimento de abertura dos documentos dos DOPS respectivos. O movimento, contudo, não frutificou (FICO, 2012).

$\mathrm{Na}$ contramão desta tendência, durante a campanha eleitoral de 2010, o Arquivo Nacional proibiu o acesso aos fundos da ditadura militar sob a alegação de que jornalistas estavam fazendo mau uso dos documentos buscando informações sobre os candidatos Dilma Rousseff e José Serra. Também estava em curso, naquele momento, uma demanda do jornal Folha de S. Paulo que pretendia ter acesso ao processo que levou Dilma Rousseff à prisão durante a ditadura militar.

Entretanto, sem dúvida o fator de maior importância para a regulamentação do acesso à informação surgiu do processo Gomes Lund vs. Brasil, que tramitou pela Comissão e pela Corte Interamericana de Direitos Humanos. Os familiares dos mortos e desaparecidos políticos da chamada Guerrilha do Araguaia ${ }^{74}$ e outros movimentos de direitos humanos movimentaram a Comissão Interamericana de Direitos Humanos desde 1995 para relatar a desídia do Brasil em promover a investigação do que teria acontecido com os "guerrilheiros".

Após vários trâmites e prazos concedidos ao Brasil para que informasse sobre as ações executadas com o propósito de implementar as recomendações da Comissão, isso não foi feito de forma satisfatória, o que a levou a submeter o caso à jurisdição da Corte Interamericana de

\footnotetext{
${ }^{74}$ A Guerrilha do Araguaia foi um movimento político iniciado em meados da década de 60, em que diversos militantes do Partido Comunista do Brasil ( $\mathrm{PCdoB})$ se dirigiram à região do Araguaia no sudeste do Pará a fim de organizar uma base de trabalho onde não houvesse assistência de Poder Público, prestando assistência às comunidades locais e transmitindo doutrinas de implantação do socialismo, com base nos exemplos cubano e chinês. Antes de que efetivamente preparassem a "guerrilha", ou seja, nos anos de preparação do movimento (entre 1970 e 1973), várias operações militares completamente sigilosas dizimaram o grupo, sem qualquer vazamento de informações à mídia ou aos familiares. As operações foram realizadas sob a ordem expressa de que ninguém deveria sair vivo, e metade dos guerrilheiros foi executada quando já havia sido capturada pelas forças militares.
} 
Direitos Humanos ${ }^{75}$, enfatizando se tratar de oportunidade de consolidação da jurisprudência interamericana sobre as leis de anistia e a obrigação dos estados de dar a conhecer a verdade à sociedade.

Em 2010, sobreveio a sentença da $\mathrm{CIDH}^{76}$. A quarta condenação do Brasil na Corte, já teve mais uma posterior em 2016 (Trabalhadores da Fazenda Brasil Verde). Além de impor a necessidade de que o Brasil investigue criminalmente os responsáveis pelas violações durante o regime repressivo, a Corte concluiu que o Brasil violou o direito de acesso à informação. A Comissão alegava diversas deficiências na legislação brasileira ${ }^{77}$, que não chegaram a ser efetivamente analisadas pela Corte. Contudo, a CIDH recomendou a edição de lei que regulamentasse o direito de acesso à informação, com previsão de procedimentos administrativos e recursos; limitações legais, específicas e com o menor grau de restrição possível; necessidade de fundamentação das negativas; e impossibilidade de imposição de sigilo em caso de violações de direitos humanos, entre outras recomendações.

O Estado brasileiro tomou diversas providências relacionadas ao cumprimento da decisão condenatória proferida pela Corte Interamericana de Direitos Humanos. Contudo, o relatório de cumprimento de sentença, elaborado em dezembro de 2011 para envio à Corte, não registra qualquer providência relacionada à persecução penal dos criminosos, principalmente face à vedação contida na Lei de Anistia, julgada constitucional pelo STF. Esta foi a primeira vez que o Brasil descumpriu decisão da Corte (ROCHA, 2014).

Diante das recomendações da CIDH e tendo em vista a impossibilidade de cumprir a determinação de persecução penal dos responsáveis, o estado agilizou o processo de edição de uma nova regulamentação do acesso à informação.

\subsection{Mecanismos de Facilitação de Acesso e Redução dos Prazos de Sigilo}

Resumidamente, a Lei de Acesso à Informação pode ser estruturada em 3 grandes pilares: a) acesso à informação: direito fundamental e dever do Estado, com suas exceções (artigos $1^{\circ}$ a $5^{\circ}$ ); b) procedimentos de transparência e divulgação (artigos $6^{\circ}$ ao 31 ); e c) responsabilidades e proteções (artigos 32 ao 47) (JUNIOR, 2015).

A lei estabelece duas vertentes para o fornecimento de informações públicas aos interessados. A primeira, denominada de ativa, consiste no dever do Estado de disponibilizar espontaneamente as informações nas páginas eletrônicas de internet de seus respectivos órgãos ou em suas repartições; a segunda, denominada de passiva, consiste na obrigação que tem o Estado, mediante provocação processual administrativa do interessado, de fornecer as informações solicitadas ou negar seu acesso de maneira fundamentada.

\footnotetext{
${ }^{75}$ A propositura de ações diretamente na Corte Interamericana de Direitos Humanos não é acessível diretamente aos indivíduos, por não serem considerados sujeitos de direito internacional. Apenas os estados-memnbros da OEA e a Comissão Interamericana de Direitos Humanos podem demandar diretamente perante a Corte. Dessa forma, os familiares e as instituições primeiramente levaram o caso ao conhecimento da Comissão, uma vez que esta é acessível aos indivíduos, e esta, após a realização dos trabalhos e a ausência de resposta por parte do estado brasileiro, demandou a atuação da Corte Interamericana.

${ }^{76}$ Esta foi a quarta condenação brasileira no sistema interamericano de direitos humanos. Em sequência, o Brasil foi condenado nos casos "Sétimo Garibaldi", "Escher", "Damião Ximenes" e o caso "Gomes Lund", de interesse deste artigo. O Brasil também foi condenado mais duas vezes recentemente: o caso dos Trabalhadores da Fazenda Brasil Verde, em 2016, e da Favela Nova Brasília, em 2017.

${ }^{77}$ Segundo a Comissão, a regulamentação brasileira não definia nem delimitava corretamente as causas de restrição do acesso à informação e não asseguravam procedimentos administrativos para a correta tramitação das solicitações e o recurso contra as decisões. Além disso, a Comissão pontuou que o Brasil não justificava adequadamente as negativas de acesso e a legislação permitia períodos de sigilo exagerados e ilegítimos. Entretanto, a Corte não chegou a analisar a legislação brasileira, por entender que os pedidos de acesso à documentos da Guerrilha do Araguaia mão foram negados com base na legislação, mas com base em sua alegada inexistência.
}

Revista de Direito Brasileira | Florianópolis, SC | v. 23 | n. 9 | p. 83-111 |Mai./Ago. 2019 
A nova legislação, na linha do que já consolidado como garantia de acesso à informação, cumpriu as determinações da CIDH. Dessa forma, trouxe procedimentos claros para a tramitação dos pedidos com o cabimento de recursos (Capítulo III da lei), a expressa desnecessidade de motivar o pedido (art. $10, \S 3^{\circ}$ ) e a exigência de fundamentação da negativa (art. $7^{\circ}, \S 4^{\circ}$ ). Além disso, reduziu os prazos de sigilo para o máximo de 25 anos (no caso de documentos ultrassecretos) e previu, com maior especificidade, as hipóteses de decretação de sigilo ${ }^{78}$ e procedimento de classificação dos documentos.

A despeito da exitosa sistematização de inúmeras regras em nossa legislação, algumas delas persistem não correspondendo às expectativas de um direito fundamental. Existem alguns dispositivos que continuam com um elevado grau de imprecisão e sujeitos a intepretações controvertidas nas mãos de autoridades públicas, quase sempre sem garantias de uma atuação independente (PERLINGEIRO, 2015). A regra de maior impacto é a que concerne às limitações do acesso à informação, onde persistem previsões genéricas, como a soberania nacional, estabilidade econômica ou segurança de instituições (incisos I, IV e VII, respectivamente, do art. 23) sendo apenas aparente a ideia de que aqui se observa estrita e rigorosamente a reserva legal. Além disso, existe a previsão ampliativa do art. 22 que rebate para qualquer outra legislação trazer uma nova hipótese de sigilo ${ }^{79}$. Na verdade, conforme refere PERLINGEIRO (2015), não há nenhuma diferença entre uma omissão legislativa e uma lei que se refira, genericamente, a expressões maleáveis e sem um sentido unívoco.

Ademais, o art. 31 ressalva pelo prazo de 100 anos a contar da sua produção todos os documentos que contenham dados pessoais, em nome da proteção da privacidade, independente de classificação de sigilo ${ }^{80}$.

Entretanto, como já anotado, existem avanços dignos e consideráveis no sentido da transparência, sendo justo afirmar que, pela primeira vez, nossa legislação trata o sigilo como exceção e o acesso como direito universal. No ponto que interessa a este trabalho, os avanços são ainda mais aparentes e elogiáveis.

Inicialmente, antes de sequer tratar das hipóteses de sigilo, a lei afirma expressamente que não pode ser negado o acesso à informação necessária à tutela judicial ou administrativa de direitos fundamentais (art. 21, caput) e que todas as informações que impliquem violação de direitos humanos praticados por (ou a mando de) agentes públicos não podem ser objeto de restrição de acesso (art. 21, parágrafo único).

No mesmo sentido a previsão do $\S 3^{\circ}$ do art. 31 , que dispensa o consentimento do interessado para acesso a documentos relacionados à defesa de direitos humanos ou à proteção de interesse público e geral preponderante. Além disso, o $\S 4^{\circ}$ do mesmo artigo ressalva da reserva de intimidade documentos importantes para a recuperação de fatos históricos de maior relevância. Dessa forma, a defesa da privacidade não pode mais ser oposta ao pedido de acesso aos arquivos e documentos da repressão.

\footnotetext{
${ }^{78} \mathrm{O}$ acesso à informação, constitucionalmente falando, só estaria sujeito a duas exceções: informações pessoais e privadas ou a segurança da sociedade e do Estado. As hipóteses previstas na Lei são os desdobramentos específicos dessas cláusulas constitucionais, reduzindo a discricionariedade da administração na classificação do documento como sigiloso.

${ }^{79}$ Art. 22. O disposto nesta Lei não exclui as demais hipóteses legais de sigilo e de segredo de justiça nem as hipóteses de segredo industrial decorrentes da exploração direta de atividade econômica pelo Estado ou por pessoa física ou entidade privada que tenha qualquer vínculo com o poder público.

${ }^{80}$ Art. 31. O tratamento das informações pessoais deve ser feito de forma transparente e com respeito à intimidade, vida privada, honra e imagem das pessoas, bem como às liberdades e garantias individuais.

$\S 10$ As informações pessoais, a que se refere este artigo, relativas à intimidade, vida privada, honra e imagem:

I - terão seu acesso restrito, independentemente de classificação de sigilo e pelo prazo máximo de 100 (cem) anos a contar da sua data de produção, a agentes públicos legalmente autorizados e à pessoa a que elas se referirem; e II - poderão ter autorizada sua divulgação ou acesso por terceiros diante de previsão legal ou consentimento expresso da pessoa a que elas se referirem.

$[\ldots]$
}

Revista de Direito Brasileira | Florianópolis, SC | v. 23 | n. 9 | p.83-111 |Mai./Ago. 2019 
Tais dispositivos devem ser celebrados, pois ratificam o princípio da publicidade que informa o acesso à informações públicas. Todavia há que se perquirir sobre o alcance da expressão "tutela judicial ou administrativa de direitos fundamentais". Segundo LEAL (2012), o dispositivo não discrimina tipos de direitos fundamentais, razão pela qual o simples acesso para fins de esclarecimento ou conhecimento histórico não pode ser negado enquanto direito social difuso.

Aliás, o segredo de Estado não pode ter respaldo ou condicionantes nos regimes democráticos contemporâneos, salvo raríssimas e muito bem justificadas situações. Todavia, mesmo nestas situações o documento será secreto não mais reportado ao seu detentor ou produtor, mas à qualidade da informação envolvida e o que está sendo protegido (LEAL, 2012). Portanto, é mais um passo no sentido da superação de um paradigma subjetivo e pessoal da administração pública ${ }^{81}$ em direção a uma feição real da coisa pública e do interesse supraindividual, privilegiando a nova feição objetivista que vem sendo atribuída à Administração Pública $^{82}$.

A nova Lei de Acesso à Informação, fruto de debates no seio dos direitos humanos e da justiça de transição, contribuiu para o aperfeiçoamento da visão objetiva da Administração Pública e para a aproximação do princípio da publicidade de uma feição material, que supera o simples formalismo da publicação em Diário Oficial. A publicidade material implica no efetivo acesso a informações e documentos públicos e a perspectiva de uso de tais dados no aprimoramento democrático.

Prevaleceu, portanto, a posição dos arquivos públicos, solucionando, de modo geral, a aparente contradição entre a proteção do direito à intimidade e o reconhecimento da importância do acesso a informações contidas em documentos públicos do período da ditadura militar (RODRIGUES, 2014). As reduções das hipóteses de sigilo, a imposição de limites aos limites e o fim do "sigilo eterno" das informações contribuiu para uma mudança efetiva.

A efetividade de tal mudança, ao menos em primeiro plano, pode ser extraída da "onda de publicização" de arquivos da ditadura que ocorreu nos últimos anos, conforme se pretende demonstrar, resumidamente, em sequência.

\subsection{Impulso à Abertura de Arquivos Públicos}

É inegável que todos os documentos comprobatórios reunidos por vítimas que pleitearam suas indenizações junto à Comissão de Anistia constituem um acervo documental peculiar, na medida em que cada processo é uma espécie de "antidossiê", o reverso dos velhos dossiês da espionagem ou da polícia política (FICO, 2012). Somando-se isso a todos os documentos produzidos pelos órgãos oficiais observamos que o Brasil é detentor de um dos maiores acervos públicos de documentos outrora sigilosos produzidos por uma ditadura militar.

Os arquivos públicos foram sendo abertos aos poucos, com grande esforço, em sua maioria após a declaração do Supremo Tribunal Federal de que os arquivos da ditadura devem ser públicos. Na realidade, grande parte da abertura pode ser situada, em uma linha do tempo, após a edição da Lei $\mathrm{n}^{\mathrm{o}}$ 12.527/2011, o que se coaduna com a grande mudança até aqui defendida.

\footnotetext{
${ }^{81}$ Segundo este paradigma pessoal, o documento é sigiloso simplesmente por ter sido produzido por ou estar em posse da Administração Pública, ou então pelo fato de o administrador, em seu arbítrio, assim entender e determinar. ${ }^{82}$ Diversos princípios e regras contribuem para uma aproximação do paradigma objetivo da Administração Pública, além das mudanças no acesso à informação pública. Algumas medidas já vem sendo aplicadas há mais tempo, como as decorrentes do princípio da impessoalidade e da vedação ao nepotismo. Recentemente, todavia, os novos paradigmas de publicidade e transparância estão sendo responsabilizados por mudanças substanciais, identificadas com maior clareza no trato das contas públicas.
} 
Como já exposto em momento anterior, o Decreto $n^{\circ} 5.584$ de 2005 determinou a transferência de acervos de diversos órgãos extintos para o Arquivo Nacional. Não obstante, o acesso continuou difícil, pois foi mantido o sigilo. Em 2006, o STF declarou que o acervo da ditadura contido nos arquivos do STM deve ser público sem restrições (RMS 23.036, já citado).

O primeiro órgão a sinalizar uma abertura substancial foi a Agência Brasileira de Inteligência, que determinou a transferência gradual de seu acervo ao Arquivo Nacional, durante os anos de 2005 e $2006^{83}$. Contudo, mesmo com tantos documentos recolhidos conjuntamente no Arquivo Nacional desde 2005, o efetivo acesso só foi liberado, de fato, em 2012, no contexto de promulgação da Lei $n^{\circ} 12.527 / 2011^{84}$. Em março de 2013, também a Casa Civil determinou a remessa de seus documentos relativos à ditadura ao Arquivo Nacional, completando mais um ciclo de concentração de arquivos no órgão ${ }^{85}$.

Em abril de 2013, o Arquivo Público de São Paulo franqueou o acesso aos documentos do extinto DEOPS (Departamento Estadual de Ordem Política e Social), o que representou um avanço considerável, diante da grande quantidade de operações militares conduzidas no ente federativo durante a ditadura ${ }^{86}$.

Em junho de 2014, em meio a uma crise diplomática causada por acusações de que o governo norte-americano estaria espionando o governo brasileiro, foram finalmente enviados ao país inúmeros documentos sobre o regime ditatorial que estavam em posse dos EUA ${ }^{87}$. Tais documentos contém informações explícitas que revelam o profundo conhecimento que detinha o governo americano sobre as torturas aqui cometidas e a forma como preferiu não intervir ${ }^{88}$. Lembrando que os Estados Unidos apoiavam os regimes ditatoriais latinos até 1977, quando passou a se opor às torturas, embora os documentos demonstrem que delas já tinham conhecimento muitos anos antes.

Após o fim dos trabalhos da Comissão Nacional da Verdade (encerrados em 2014), até mesmo a Igreja Católica da Argentina cedeu arquivos sobre o período ditatorial brasileiro, em $2016^{89}$. No mesmo ano, os EUA iniciaram a cessão de documentos ao governo argentino sobre a ditadura no país, que contêm informações valiosas também sobre o governo brasileiro e a centralidade a ele atribuída pelo governo norte-americano à época ${ }^{90}$.

Em outubro de 2016, a Cruz Vermelha retirou o sigilo sobre documentos guardados em Genebra há mais de meio século, revelando detalhes sobre massacres de indígenas cometidos

83 Disponível em: http://www.arquivonacional.gov.br/br/difusao/arquivo-na-historia/686-recolhimento-do-acervodo-sni-ao-arquivo-nacional.html. Acesso em 06/02/2019.

84 Disponível em: https://oglobo.globo.com/brasil/arquivo-nacional-vai-abrir-acervo-da-ditadura-ao-publico5062610. Acesso em 06/02/2019.

85 Disponível em: https://www1.folha.uol.com.br/poder/2013/03/1239994-casa-civil-decide-liberar-papeis-daditadura-militar.shtml. Acesso em 06/02/2019.

${ }_{86}$ Disponível em: http://www.brasil.gov.br/cidadania-e-justica/2013/04/documentos-da-ditadura-estao-disponiveisna-internet. Acesso em 06/02/2019.

87 Disponível em: http://www.casacivil.gov.br/central-de-conteudos/noticias/2015/julho/presidencia-da-republicarecebe-do-governo-norte-americano-documentos-relacionados-a-ditadura-militar-no-brasil. Acesso em 06/02/2019.

${ }^{88}$ Tais documentos contem informações sobre a morte de Stuart Angel Jones, um integrante da luta armada brasileira cujo desaparecimento atraiu a atenção da mídia por ser filho da estilista Zuzu Angel. A estilista levou o desparecimento de seu filho à atenção da mídia internacional, mas não obteve respostas sobre o desaparecimento do filho. Zuzu morreu misteriosamente em $1976 \mathrm{em}$ um acidente de carro, sem ter notícias do paradeiro de seu filho. Em 2014, restou confirmada a participação das forças repressivas na morte da estilista; além disso, os documentos enviados pelo governo norte-americano no mesmo ano contem as informações sobre a morte de Stuart Angel, que também era cidadão norte-americano.

${ }^{89}$ Disponível em: https://exame.abril.com.br/mundo/vaticano-confirma-abertura-de-arquivos-da-ditadura-argentina/. Acesso em 06/02/2019.

${ }^{90}$ Disponível em: https://exame.abril.com.br/mundo/eua-publicam-documentos-sobre-ditadura-na-argentina/. Acesso em 06/02/2019. 
durante a ditadura militar brasileira e sobre as técnicas de tortura então utilizadas, adicionando uma faceta até então desconhecida à brutalidade do regime ${ }^{91}$.

O Arquivo Público do Distrito Federal, por fim, providenciou a abertura de seus arquivos apenas no início de 2017, contendo documentos da Secretaria de Segurança Pública e Paz Social ${ }^{92}$.

Todo este movimento foi possível apenas com a promulgação da Lei $\mathrm{n}^{\circ} 12.527 / 2011$, ainda quando tratamos dos documentos enviados pelo exterior. Não podemos esquecer que a referida lei possibilitou o trabalho da Comissão Nacional da Verdade, exercendo pressão pela negociação de arquivos em posse de outros países.

\subsection{Desafios de Aplicação da Legislação}

Apesar dos grandes avanços obtidos com a nova legislação e com a atuação da Comissão da Verdade, permanecem desafios para o acesso à informação pelo Estado brasileiro no período ditatorial em dois aspectos principais: o "desaparecimento" de muitos documentos do Sistema Nacional de Informações e Contrainformação (Sisni) e a ausência de tratamento arquivístico adequado de diversos acervos públicos e privados de interesse para a reconstrução da memória histórica, não permitindo a conservação dos documentos nem a difusão das informações neles contidas.

Conforme estudo citado por RODRIGUES (2014), dos 249 órgãos identificados como componentes desse sistema, apenas $20 \%$ tiveram seus acervos recolhidos ao Arquivo Nacional até 2014, sendo que a maior parte dos conjuntos documentais do SISNI ainda não foi localizada ${ }^{93}$.

Se considerarmos todo esse conjunto, percebemos a existência de um rico patrimônio documental sobre o período da ditadura ainda a ser descoberto e tratado.

Um exemplo é o Superior Tribunal Militar. TORELY (2012) afirma que as políticas de transição cabem prioritariamente ao Executivo e Legislativo, cabendo ao Judiciário a reparação às vítimas e a não obstaculizar o processo de transição. O STM, contudo, possui um histórico de negativas de pedidos de acesso aos documentos. Em março de 2017 o STF deu provimento a uma reclamação, reiterando o entendimento já firmado no julgamento do RMS 23.036 e determinando que o STM a facilitar o acesso.

O STM, em resposta, afirma que os arquivos sempre foram públicos e não foi imposto qualquer óbice ao seu acesso. Todavia, devemos lembrar o passado de roubos de arquivos do STM como única forma de acesso (CATELA, 2011). O maior exemplo de resistência aos arquivos fechados do Tribunal é o dossiê "BRASIL. NUNCA MAIS", produzido pela arquidiocese de São Paulo mediante infiltração e acesso secreto aos inúmeros documentos proibidos. Entre 2016 e 2017, a Corte Militar publicou editais para habilitação de interessados no acesso aos documentos.

Além disso, devemos nos lembrar de todos os arquivos que se encontram retidos em Ministérios, mesmo após a Lei de Acesso à Informação e os trabalhos da Comissão da Verdade ${ }^{94}$.

\footnotetext{
91 Disponível em: https://apublica.org/2016/10/documentos-da-cruz-vermelha-revelam-massacre-de-indigenas-naditadura/. Acesso em 06/02/2019.

92 Disponível em: http://www.casacivil.df.gov.br/arquivo-publico-do-df-abre-documentos-da-epoca-da-ditaduramilitar/. Acesso em 06/02/2019.

${ }^{93}$ Nessa cota de documentos não localizados, estão incluídos os acervos documentais do Centro de Inteligência do Exército (CIE), do Centro de Informações da Marinha (CENIMAR) e do Centro de Informação de Segurança da Aeronáutica (CISA). Tais arquivos, em tese, poderiam conter informações de relevo sobre o período que não foram documentadas por nenhum outro órgão.

${ }^{94}$ Segundo reportagem do jornal A Folha de São Paulo, em 2013, pelo menos 9 pastas ainda possuía documentos com acesso negado: http://www1.folha.uol.com.br/poder/2013/03/1239837-documentos-da-ditadura-sao-retidos-porministerios.shtml
} 
Fulcral é o caso das empresas públicas da época que vieram a ser privatizadas durante o governo FHC, como a EMBRAER, a Companhia Siderúrgica Nacional e a Usiminas. Vale lembrar aqui a já referida impossibilidade de que o direito administrativo chancele a fuga do Estado ao direito privado (WOLF, 2006). O Arquivo Nacional tenta fazer com que estas empresas cedam os arquivos da ditadura, mas encontra forte resistência. Nem a Comissão da Verdade conseguiu acesso a estes documentos ${ }^{95}$. Além disso, existem inúmeras empresas estrangeiras, em especial as montadoras, que ajudavam o governo a identificar sindicalistas subversivos em sua folha de pagamento, como a Volkswagen e a Ford, por exemplo.

Por fim, são relatados ${ }^{96}$ diversos problemas no acesso a documentos em posse de Universidades, ressaltando a enorme influência dos órgãos de controle e monitoramento das atividades universitárias.

Como se observa, apesar dos inúmeros avanços com a Comissão da Verdade e a Lei de Acesso à Informação, ainda persiste um grande acervo a ser explorado e confrontado memorialmente, embora já se identifique um esfriamento das reivindicações por justiça de transição.

\section{CONCLUSÃO}

Conforme se demonstrou, a justiça de transição, enquanto processo político e jurídico, impulsionou mudanças de grande monta no direito interno, em particular nas suas implicações com o direito à publicidade e ao acesso à informação.

SANTOS (2010) demonstra a relevância muito maior dos entes de direitos humanos na realização da construção da memória histórica do que do próprio estado. Este teria, na verdade, assumido posturas contraditórias. Segundo a autora, a literatura de justiça de transição tende a assumir uma linearidade na atuação do estado, privilegiando as "novas elites políticas", o que não acontece.

O caso da Guerrilha do Araguaia demonstrou que novas democracias, como a brasileira, muitas vezes não rompem totalmente com as estruturas de poder que davam sustentação ao regime anterior; tampouco transformam simultaneamente as culturas jurídicas de todos os setores do Estado e da sociedade. (SANTOS, 2010).

Todavia, a decisão do caso Gomes Lund foi tão importante que gerou até mesmo ações penais, ainda que a admissibilidade das imputações tivesse que apelar às alegações de permanência do crime (ROCHA, 2014). A pretensão é deveras importante, uma vez que existem estudos que demonstram, empiricamente, que Estados que julgaram os responsáveis por violações de direitos humanos apresentam melhora significativa na preservação de direitos básicos da população (NOHARA, 2009).

O Brasil, contudo, "se virou" da forma que pôde. Em um ordenamento em que vige a exigência da documentação administrativa, o direito de acesso é um parâmetro fundamental para se por à prova o sistema democrático e a centralidade da cidadania (LEAL, 2012), por constituir elemento essencial da participação política.

Tais reivindicações de direito à verdade, direito à memória e acesso aos documentos registram como os arquivos da repressão foram e são mobilizadores enquanto memória do

\footnotetext{
${ }^{95} \mathrm{O}$ caso da CSN é peculiar, pois até o MPF reivindica acesso aos arquivos. Em 1988, uma greve foi violentamente encerrada com intervenção militar, e 5 anos depois ela foi privatizada. Se após a redemocratização houve esse enorme envolvimento militar, imagine durante o auge da repressão. O MPF recomendou em março de 2016 que a CSN libere os documentos. Depois disso, seu acesso foi franqueado e os documentos vêm sendo analisados pela Comissão de Verdade do RJ.

96 A esse respeito, confira-se artigo acerca dos problemas no acesso a documentos do período militar na UFES: http://www.revistas.udesc.br/index.php/tempo/article/view/2175180305102013295/2874.
}

Revista de Direito Brasileira | Florianópolis, SC | v. 23 | n. 9 | p.83-111 |Mai./Ago. 2019 
arbítrio. Como demonstrado, sua força mobilizadora modernizou parâmetros democráticos até então estabelecidos em patamares insuficientes, como a transparência e o acesso à informação pública.

Observa-se que o direito administrativo, sob esta ótica, assume função fundamental de possibilitar também a concretização de direitos humanos no âmbito interno, ainda que sob impulsos internacionais ou paraestatais (arenas informais). A ressignificação dos instrumentos de direito administrativo afasta-o de um paradigma subjetivista, que privilegia o caráter meramente estatal das ações, aproximando de uma visão objetiva e, de certa forma, impessoal.

O sigilo é exemplo dessa modificação: não mais se estabelece pelo simples caráter estatal da fonte produtora ou detentora da informação. O que importa é seu conteúdo e a forma como pode prejudicar ou auxiliar no interesse público. No caso de arquivos da ditadura, como ficou consagrado, o sigilo atrapalha o interesse público na consolidação democrática. $\mathrm{O}$ acesso aos documentos oficiais é instrumental para a participação política do cidadão e para o controle das instituições. Sem tais possibilidades, o aperfeiçoamento democrático se encontra prejudicado, impedindo o desenvolvimento de uma democracia que já foi tão profundamente abalada.

Extrai-se da hipótese central verificada nesse artigo que o direito à verdade e as modernizações dogmáticas trazidas pela lei de acesso à informação inclinaram a balança da publicidade em desfavor do sigilo estatal, ocasionando movimento de abertura dos arquivos da repressão. A visão meramente formal da publicidade como publicação dos atos em Diário Oficial revela a sua insuficiência: é necessária uma publicidade efetiva e material, que ultrapassa a "publicação" e alcança o conhecimento e a utilização da informação, principalmente quando esta diz respeito a um passado de repressão.

\section{REFERÊNCIAS BIBLIOGRÁFICAS}

ABRÃO, Paulo; TORELLY, Marcelo D. Mutações do Conceito de Anistia na Justiça de Transição Brasileira: A Terceira Fase de Luta pela Anistia. Revista de Direito Brasileira, vol. 3, p. 357, jul., 2012.

AGAMBEN, Giorgio. Estado de Exceção. 2a Ed. São Paulo: Boitempo, 2004.

ALDER, John. General Principles of Constitutional and Administrative Law. $4^{\mathrm{a}}$ Ed. Nova Iorque: PalgraveMacmillan, 2002.

ALENCAR, RosmarAntonni Rodrigues Cavalcanti de. Direito à Memória e Aspectos Criminais: a ditadura militar e os efeitos da anistia. Revista dos Tribunais, vol. 952, p. 195-211, fev., 2015.

ARENDT, Hannah. Entre o passado e o futuro. $5^{\text {a }}$ ed. São Paulo: Perspectiva, 2003.

BAUER, Caroline Silveira. Brasil e Argentina: ditaduras, desaparecimentos e políticas de memória. Porto Alegre: Medianiz, 2012.

BOBBIO, Norberto. Estado, Governo e sociedade - Para uma teoria geral da política. Trad. Marco Aurélio Nogueira. Rio de Janeiro: Paz e Terra, 1987.

BRADLEY, A. W.; EWING, K. D. Constitutional and administrative law. 14 ${ }^{\mathrm{a}}$ ed. London: Pearson, 2007. 
BRASIL. Direito à verdade e à memória: Comissão Especial sobre Mortos e Desaparecidos Políticos. Brasília: Secretaria Especial dos Direitos Humanos, 2007.

. Nunca mais. Arquidiocese de São Paulo. 37ª ed. Petrópolis: Vozes, 2009.

CARRARA, Sergio. Do direito de saber: o acesso à informação pessoal privada nos arquivos da ditadura militar brasileira. Revista Acervo. vol. 24, n. 1, p. 197. Rio de Janeiro: Arquivo Nacional, jan./jun. 2011.

CATELA, Ludmila da Silva. O Mundo dos Arquivos. In: REÁTEGUI, Félix (org.). Justiça de Transição: manual para a América Latina. Brasília: Comissão de Anistia, Ministério da Justiça; Nova Iorque: Centro Internacional para Justiça de Transição, 2011, p. 379-401.

COELHO ZILLI, Marcos Alexandre; MONTECONRADO GHIDALEVICH, Fabíola Girão; MOURA, Maria Thereza Rocha de Assis. Brasil. In: AMBOS, Kai; ELSNER, Gisela; MALARINO, Ezequiel. Justicia de Transición: con informes de América Latina, Alemanha, Itália y España. Montevideo: Konrad-Adenauer, 2009.

CONTROLADORIA Geral da União. Acesso à Informação Pública: uma introdução à Lei n. 12.527, de 18 de novembro de 2011. Brasília: Imprensa Nacional, 2012.

CUYA, Esteban. Justiça de Transição. Revista Acervo. vol. 24, n. 1, p. 37. Rio de Janeiro: Arquivo Nacional, jan./jun. 2011.

EBBESSON, Jonas. Acesso à Informação, Participação Pública e Acesso à Justiça em Matéria Ambiental: uma breve introdução à Convenção de Aarhus. Revista de Direito Ambiental, vol. 64, p. 29-41, out./dez., 2011.

FICO, Carlos. História do Tempo Presente, eventos traumáticos e documentos sensíveis. Varia Historia, Belo Horizonte, vol. 28, nº 47, p.43-59, jan./jun., 2012.

FOUCAULT, Michel. A verdade e as formas jurídicas. $3^{\text {a }}$ ed. Rio de Janeiro: Nau, 2002.

GREEN, James N. A proteção da privacidade com a abertura plena dos arquivos. Revista Acervo. vol. 24, n. 1, p. 211. Rio de Janeiro: Arquivo Nacional, jan./jun. 2011.

HABERMAS, Jürgen. Consciência Moral e Agir Comunicativo. Rio de Janeiro: Tempo Brasileiro, 1989.

JUNIOR, João Francisco da Mota. O Direito à Informação e o Acesso a Documentos Públicos da Ditadura Militar: A Proteção pela Jurisdição Constitucional. Interfaces Científicas. Aracaju: vol. 3, n. 2, p. 57-71, fev., 2015.

JUNIOR, Wallace Paiva Martins. Transparência Administrativa: publicidade, motivação e participação popular. São Paulo: Saraiva, 2004.

KONRAD, Glaucia Vieira Ramos; LOPES, Janaina Vedoin. Arquivos da Repressão e Leis de Acesso à Informação: os casos brasileiro e argentino na construção do direito à memória e à verdade. Revista AEDOS, nº 13, vol. 5, p. 6-23, ago./dez., 2013. 
LEAL, Rogério Gesta. Verdade, memória e justiça no Brasil: responsabilidades compartidas. Porto Alegre: Livraria do Advogado, 2012.

. A Difícil Relação entre o Direito Fundamental à Informação e o Acesso aos Documentos Produzidos pelo Regime Militar Brasileiro. Revista de Direito Brasileira, vol. 1, p. 141, jul., 2011.

; RAMOS, Taís. Desafios à Efetivação do Acesso à Informação Referente aos Documentos do Regime Militar em Face dos seus Novos Marcos Normativos. Revista de Direito Brasileira, vol. 3, p. 407, jul./dez., 2012.

MAILLART, Adriana Silva; SANCHES, Samyradal Farra Naspolini. A Decisão da Corte Interamericana de Direitos Humanos no Caso Gomes Lund e Outros - Guerrilha do Araguaia. Revista de Direito Brasileira, vol. 3, p. 463-472, jul./dez., 2012.

MARTINS, Paula Ligia. Acesso à informação: um direito fundamental e instrumental. Revista Acervo. vol. 24, n. 1, p. 236. Rio de Janeiro: Arquivo Nacional, jan./jun. 2011.

MENDEL, Toby. O Direito a Informação na América Latina. UNESCO, 2009. Disponivel em: <http://bit.ly/1MVf6BA >. Acessoem: 19/06/2017.

. The Public's Right to Know. Principles on Freedom of Information Legislation.London: ARTICLE 19, 1999. Disponivel em: <http://bit.ly/11YHR4n>. Acesso em: 19/06/2017.

NOHARA, Irene Patrícia. Direito à memória e reparação: da inclusão jurídica das pessoas perseguidas e torturadas na ditadura militar brasileira. Revista de Direito Constitucional e Internacional, vol. 67, p. 125-161, abr./jun., 2009.

PERLINGEIRO, Ricardo. Garantias do Direito à Verdade e do Acesso à Informação na Justiça de Transição na América Latina. Revista de Direito Constitucional e Internacional, vol. 93, p. 137-148, out./dez., 2015.

; DÍAZ, Ivonne; LIANI, Milena. Princípios sobre o direito de acesso à informação oficial na América Latina. Revista de Investigações Constitucionais, Curitiba, vol. 3, n. 2, p. 143-197, maio/ago., 2016.

PIOVESAN, Flávia. Direitos humanos e o direito constitucional internacional. 10ª ed. São Paulo: Saraiva, 2009.

PONTA, Gisele Ime Motta; ZAMBOTTO, MartanParizzi. A Verdade e a Política. Revista de Direito Constitucional e Internacional, vol. 77, p. 373-394, set./out., 2016.

REÁTEGUI, Félix. As Vítimas Recordam: notas sobre a pratica social da memória. In: REÁTEGUI, Félix (org.). Justiça de Transição: manual para a América Latina. Brasília: Comissão de Anistia, Ministério da Justiça; Nova Iorque: Centro Internacional para Justiça de Transição, 2011, p. 357-378.

ROCHA, Fernando A. N. Galvão da. Crimes da ditadura militar: cumprimento da decisão da Corte Interamericana de Direitos Humanos no caso Gomez Lund. Revista Brasileira de Ciências Criminais, vol. 108, p. 261-296, maio/jun., 2014. 
RODRIGUES, Vicente Arruda Câmara. Lenta, Gradual e Segura? A Comissão Nacional da Verdade e a Lei de Acesso a Informações na Construção da Justiça de Transição no Brasil. Revista Acervo. vol. 27, n. 1, p. 183. Rio de Janeiro: Arquivo Nacional, jan./jun. 2014.

SANTOS, Cecilia MacDowell. Memória na Justiça: A mobilização dos direitos humanos e a construção da memória da ditadura no Brasil. Revista Crítica de Ciências Sociais, vol. 88, p. 127154, mar. 2010.

SILVEIRA, Marco Antônio Karam. Lei de Acesso à Informação Pública (Lei 12.527/2011) Democracia, República e Transparência no Estado Constitucional. Revista dos Tribunais, vol. 927, p. 131, jan. 2013.

SIMON, Jan-Michael. O esclarecimento da verdade sobre graves violações dos direitos humanos. Revista Brasileira de CiênciasCriminais, vol. 92, p. 403-427, set./out., 2011.

SOMMERMANN, Karl-Peter, La exigencia de una Administración transparente en la perspectiva de los principios de democracia y del Estado de Derecho. In: GARCÍA MACHO, Ricardo (org.). Derecho administrativo de la información y administración transparente. Madrid: Marcial Pons, 2010. p. 12-19.

TEITEL, Ruti. Transitional Justice Genealogy. Harvard Human Rights Journal, n. 16, p. 69, 2003.

TORELLY, Marcelo D. Justiça de Transição e Estado Constitucional de Direito: perspectiva teórico-comparativa e análise do caso brasileiro. Belo Horizonte: Fórum, 2012.

VAN ZYL, Paul. Promovendo a Justiça Transicional em Sociedades Pós-Conflito. In:

REÁTEGUI, Félix (org.). Justiça de Transição: manual para a América Latina. Brasília:

Comissão de Anistia, Ministério da Justiça; Nova Iorque: Centro Internacional para Justiça de Transição, 2011, p. 47-71.

WOLF, Hans J.; BACHOF, Otto; STOBER, Rolf. Direito Administrativo. v. 1. Tradução de Antônio F.de Souza. Lisboa: Fundação Calouste Gulbenkian, 2006.Disponível em: <http://bit.ly/1Q4OEYe>. Acesso em: 19/06/2017.

ZILLI, Marcos. O Regime Militar e a Justiça de Transição no Brasil: para onde caminhar? Revista Brasileira de CiênciasCriminais, vol. 93, p. 61-102, nov./dez., 2011. 